\title{
Impaired $\beta$-glucocerebrosidase activity and processing in frontotemporal dementia due to progranulin mutations
}

Andrew E. Arrant ${ }^{1,2^{*}}$, Jonathan R. Roth ${ }^{1}$, Nicholas R. Boyle ${ }^{1}$, Shreya N. Kashyap ${ }^{1}$, Madelyn Q. Hoffmann ${ }^{1}$, Charles F. Murchison ${ }^{1,3}$, Eliana Marisa Ramos ${ }^{4}$, Alissa L. Nana ${ }^{5}$, Salvatore Spina ${ }^{5}$, Lea T. Grinberg 5,6, Bruce L. Miller ${ }^{5}$, William W. Seeley ${ }^{5,6}$ and Erik D. Roberson ${ }^{1,7^{*}}$ (D)

\begin{abstract}
Loss-of-function mutations in progranulin (GRN) are a major autosomal dominant cause of frontotemporal dementia. Most pathogenic GRN mutations result in progranulin haploinsufficiency, which is thought to cause frontotemporal dementia in GRN mutation carriers. Progranulin haploinsufficiency may drive frontotemporal dementia pathogenesis by disrupting lysosomal function, as patients with GRN mutations on both alleles develop the lysosomal storage disorder neuronal ceroid lipofuscinosis, and frontotemporal dementia patients with GRN mutations (FTD-GRN) also accumulate lipofuscin. The specific lysosomal deficits caused by progranulin insufficiency remain unclear, but emerging data indicate that progranulin insufficiency may impair lysosomal sphingolipidmetabolizing enzymes. We investigated the effects of progranulin insufficiency on sphingolipid-metabolizing enzymes in the inferior frontal gyrus of FTD-GRN patients using fluorogenic activity assays, biochemical profiling of enzyme levels and posttranslational modifications, and quantitative neuropathology. Of the enzymes studied, only $\beta$-glucocerebrosidase exhibited impairment in FTD-GRN patients. Brains from FTD-GRN patients had lower activity than controls, which was associated with lower levels of mature $\beta$-glucocerebrosidase protein and accumulation of insoluble, incompletely glycosylated $\beta$-glucocerebrosidase. Immunostaining revealed loss of neuronal $\beta$ glucocerebrosidase in FTD-GRN patients. To investigate the effects of progranulin insufficiency on $\beta$ glucocerebrosidase outside of the context of neurodegeneration, we investigated $\beta$-glucocerebrosidase activity in progranulin-insufficient mice. Brains from $\mathrm{Grn}^{-1-}$ mice had lower $\beta$-glucocerebrosidase activity than wild-type littermates, which was corrected by AAV-progranulin gene therapy. These data show that progranulin insufficiency impairs $\beta$-glucocerebrosidase activity in the brain. This effect is strongest in neurons and may be caused by impaired $\beta$-glucocerebrosidase processing.
\end{abstract}

Keywords: Progranulin, Lysosome, $\beta$-Glucocerebrosidase, Glycosphingolipid, Frontotemporal dementia, Neuronal Ceroid Lipofuscinosis

\section{Introduction}

Loss-of-function mutations in progranulin $(G R N)$ are an autosomal dominant cause of frontotemporal dementia (FTD), causing as much as $5-10 \%$ of FTD cases $[5,16,20]$. Most of these mutations cause progranulin

\footnotetext{
* Correspondence: andrewarrant@uabmc.edu; eroberson@uabmc.edu 1 Departments of Neurology and Neurobiology, Center for

Neurodegeneration and Experimental Therapeutics, Alzheimer's Disease Center, Evelyn F. McKnight Brain Institute, University of Alabama at Birmingham, Birmingham, AL, USA

Full list of author information is available at the end of the article
}

haploinsufficiency, with GRN carriers having less than half of normal circulating progranulin levels [19]. In rare cases, individuals have been found with loss-of-function GRN mutations on both alleles, resulting in an almost complete loss of progranulin [2, 59]. Instead of FTD, these individuals develop a lysosomal storage disorder, neuronal ceroid lipofuscinosis (NCL), characterized by neurodegeneration and accumulation of lysosomal storage material $[2,59]$. Brains from FTD-GRN patients accumulate similar storage material as NCL patients [25, 67], so lysosomal dysfunction may be a key mechanism of FTD-GRN pathogenesis. 
Understanding how the lysosome is impaired by progranulin insufficiency may enable targeted therapies for FTD due to GRN mutations. Emerging data indicate that progranulin may regulate activity of lysosomal enzymes involved in sphingolipid metabolism. Progranulin interacts with and facilitates lysosomal localization of prosaposin $[45,73,74]$, a pro-protein which is cleaved into saposin fragments that serve as critical co-factors for sphingolipid-metabolizing enzymes [57, 58]. Progranulin insufficiency disrupts prosaposin trafficking in the brain [74]. In some cell types, progranulin regulates trafficking and activity of at least two enzymes involved in sphingolipid metabolism, $\beta$-hexosaminidase A (HexA) [14] and $\beta$-glucocerebrosidase (GCase) $[29,30]$. We therefore hypothesized that progranulin insufficiency would impair activity of sphingolipid-metabolizing enzymes in the brain. To test this hypothesis, we measured enzyme activity, levels, and post-translational modifications in inferior frontal gyrus of FTD-GRN patients and frontal cortex of progranulin-insufficient mice. We assessed the interaction of progranulin with GCase in cultured cells and investigated the effects of AAV-progranulin gene therapy on GCase enzyme activity in $\mathrm{Grn}^{-/-}$mice.

\section{Materials and methods}

\section{Patient brain samples}

Post-mortem brain samples were provided by the Neurodegenerative Disease Brain Bank at the University of California, San Francisco. Brains were donated with the consent of the patients or their surrogates in accordance with the Declaration of Helsinki, and the research was approved by the University of California, San Francisco Committee on Human Research. Tissue blocks were dissected from the inferior frontal gyrus of 5 controls and 7 patients with FTD-GRN. All patients with FTD-GRN carried a pathogenic variant in GRN and had FTLD-TDP, Type A identified at autopsy, except one (case 7) discussed more extensively in the text. More extensive patient characteristics are provided in Table 1. Clinical and neuropathological diagnoses were made using standard diagnostic criteria $[23,35,36,43,53]$. GBA sequencing data were available for a subset of patients. These samples were screened by targeted sequencing of a panel of genes implicated in neurodegenerative disorders [52]. Coding and exon-intron boundary regions of the $G B A$ gene were screened for pathogenic variants classified according to the American College of Medical Genetics and Genomics and the Association for Molecular Pathology guidelines [54]. All patients with available data (1 control and 4 FTD-GRN patients) were negative for pathogenic $G B A$ variants.

\section{Animals}

$\mathrm{Grn}^{-1-}$ mice were generated and crossed onto a C57BL/6 J background as previously described [18, 37]. Wild-type,
$\mathrm{Grn}^{+/-}$, and $\mathrm{Grn}^{-/-}$mice for this study were generated by crossing male and female $\mathrm{Grn}^{+/-}$mice. The resulting littermates were used for all mouse studies, and both male and female littermates were used. The mice were housed in a barrier facility accredited by the Association for Assessment and Accreditation of Laboratory Animal Care, under conditions previously described [4]. All experiments were approved by the Institutional Animal Care and Use Committee of the University of Alabama at Birmingham.

\section{Fibroblasts}

Fibroblast lines were purchased from the NIGMS Human Genetic Cell Repository at the Coriell Institute for Medical Research. We analyzed cells from an apparently healthy line (\#GM00730), a heterozygous GBA L444P line (\#GM00878), and two homozygous GBA L444P lines (\#GM08760 and GM00877). Fibroblasts were cultured in MEM (Corning Life Sciences) with 15\% fetal bovine serum (Atlanta Biologicals) and $1 \%$ penicillin/streptomycin (ThermoFisher) at $37^{\circ} \mathrm{C}$ and $5 \% \mathrm{CO}_{2}$. Deglycosylation reactions were carried out on $25 \mu \mathrm{g}$ of protein as described below.

\section{Tissue preparation}

For initial western blot and lysosomal activity assays, tissue from mouse frontal cortex or human inferior frontal gyrus was homogenized in lysis buffer $(50 \mathrm{mM}$ Tris, 150 $\mathrm{mM} \mathrm{NaCl}, 5 \mathrm{mM}$ EDTA, 1\% Triton X-100, 0.1\% sodium deoxycholate) and spun at $5000 \times \mathrm{g}$ for $10 \mathrm{~min}$. Protein content of the supernatant was measured by Bradford assay, and equal amounts of total protein from each sample were used for subsequent assays.

\section{Western blot}

Samples were run on $4-12 \%$ bis-tris polyacrylamide gels (ThermoFisher), transferred to Immobilon-FL PVDF (MilliporeSigma), and probed overnight with primary antibody. The following primary antibodies were used: rabbit polyclonal GCase (\#G4171, MilliporeSigma), mouse monoclonal GCase (\#sc-166,407, Santa Cruz Biotechnology), cathepsin D (goat polyclonal, \#sc-6486, Santa Cruz Biotechnology), LAMP-1 (mouse monoclonal, \#sc-20,011, Santa Cruz Biotechnology), LAMP-2 (mouse monoclonal, \#sc-18,822, Santa Cruz Biotechnology), GAPDH (mouse monoclonal, \#MAB374, MilliporeSigma), Flag (mouse monoclonal, \#F3165, MilliporeSigma), and progranulin (rabbit polyclonal, \#40-3400, ThermoFisher). Blots were then probed with species-matched IRdye-conjugated secondary antibodies (Li-COR Biosciences) and scanned on an Odyssey scanner (Li-COR Biosciences).

\section{Lysosomal activity assays}

Activity of $\beta$-galactosidase ( $\beta$-Gal), $\beta$-hexosaminidase (total) (Hex), $\beta$-hexosaminidase A (HexA), $\alpha$-galactosidase A (GLA), and $\beta$-glucocerebrosidase (GCase) was 


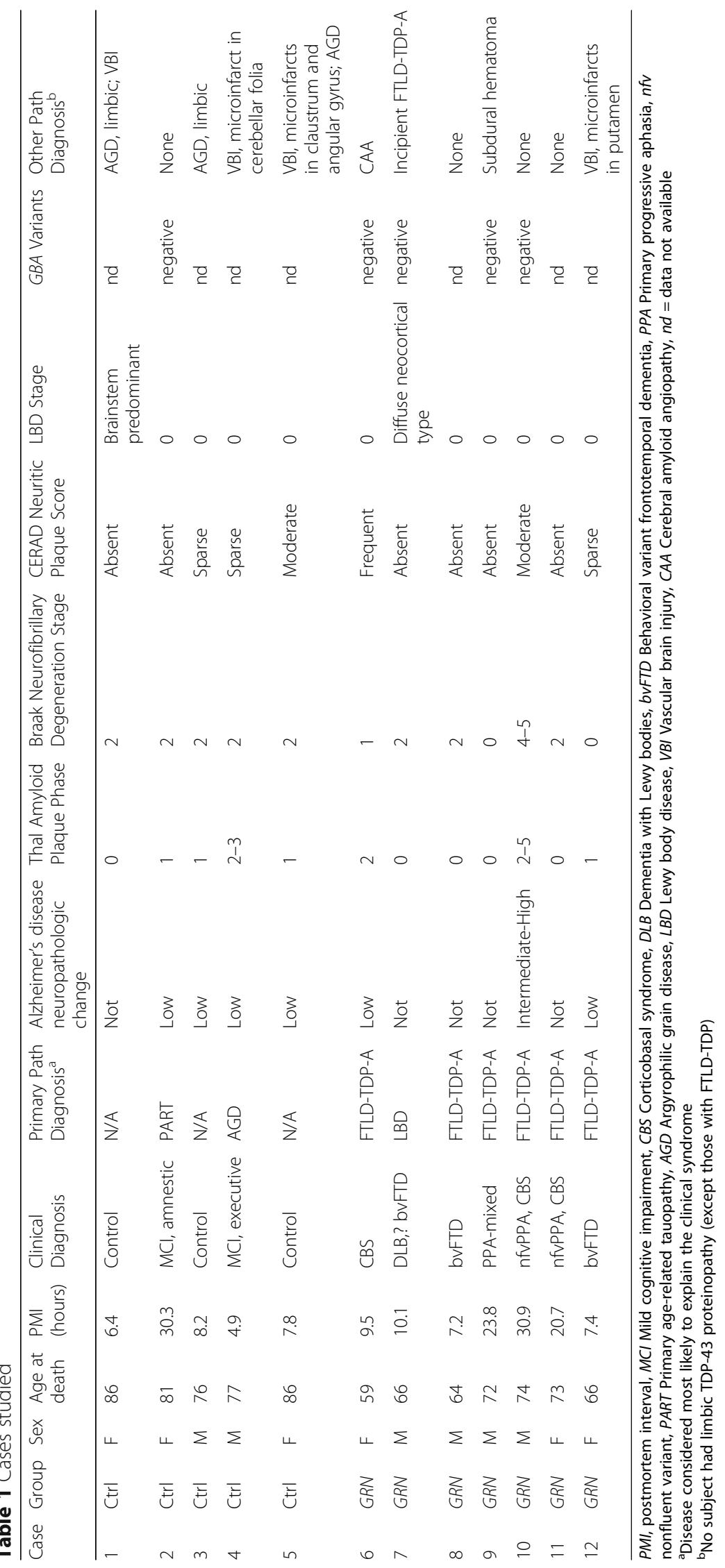


determined in tissue lysates by incubation with fluorogenic substrates at $37^{\circ} \mathrm{C}$. All reactions resulted in production of the fluorophore 4-methylumbelliferone (4-MU), and were read on a Synergy 2 plate reader (Biotek Instruments) with a $360 \mathrm{~nm}$ excitation wavelength and a $440 \mathrm{~nm}$ emission wavelength. Data were quantitated relative to a standard curve of 4-MU run on each plate and calculated as nmol 4-MU generated per hour per mg of protein loaded. For all reactions, a uniform amount of protein was loaded per well, ranging from 5 to $20 \mu \mathrm{g}$ depending on the assay.

Activity of Hex and HexA was determined by incubation with $2 \mathrm{mM}$ substrate (for $\beta$-Hex - 4-methylumbelliferyl-2acetamido-2-deoxy- $\beta$-D-glucopyranoside, MilliporeSigma, for HexA - 4-methylumbelliferyl-2-acetamido-2-deoxy-6sulfate- $\beta$-D-glucopyranoside, Research Products International) in $10 \mathrm{mM}$ sodium citrate buffer, $\mathrm{pH} 4.2$ [69]. Reactions were stopped with $0.2 \mathrm{M}$ glycine, $0.2 \mathrm{M}$ sodium carbonate.

Activity assays for GCase (substrate: $1 \mathrm{mM}$ 4Methylumbelliferyl $\beta$-D-glucopyranoside, MilliporeSigma), GLA (substrate: $4.3 \mathrm{mM}$ 4-Methylumbelliferyl $\alpha$-D-galactopyranoside, MilliporeSigma) and $\beta$-Gal (substrate: $1 \mathrm{mM}$ 4-Methylumbelliferyl $\beta$-D-galactopyranoside, MilliporeSigma) were conducted in $\mathrm{pH} 4.6$ citrate phosphate buffer and stopped with $0.4 \mathrm{M}$ glycine, $\mathrm{pH} 10.8$. For GCase, the reaction buffer included $1 \%$ bovine serum albumin, $0.25 \%$ triton X-100, 0.25\% taurocholic acid, and $1 \mathrm{mM}$ EDTA [44]. Specific GCase activity was confirmed by correcting for fluorescence generated in the presence of a GCase inhibitor, $0.18 \mathrm{mM}$ conduritol $\beta$-epoxide (Enzo Life Sciences). Specific GLA activity was determined by inhibition of non-specific substrate cleavage by $\alpha$ galactosidase B using $90 \mathrm{mMN}$-acetyl-D-galactosamine (MilliporeSigma) [44].

\section{Endoglycosidase $\mathrm{H}$ and PNGase $\mathrm{F}$ treatment}

Tissue lysates prepared as described above were incubated with endoglycosidase $\mathrm{H}$ (New England Biolabs) or PNGase F (New England Biolabs) according to the manufacturer's instructions as previously described [3]. For each sample, a control tube was run for each enzyme that contained all reaction components except for the enzyme. Reactions containing $50 \mu \mathrm{g}$ of protein were incubated overnight at $37^{\circ} \mathrm{C}$, then processed for western blot as described above.

\section{Sarkosyl soluble/insoluble fractionation}

Sarkosyl soluble and insoluble fractions were prepared using a previously described protocol [17]. Protein content of the fractions was determined by BCA assay (ThermoFisher), and equivalent amounts of protein from each sample were processed for western blot as described above.

\section{Immunostaining}

Formalin-fixed blocks of inferior frontal gyrus were provided by the Neurodegenerative Disease Brain Bank at the University of California, San Francisco. Tissue blocks were cryoprotected in $30 \%$ sucrose and cut into $30 \mu \mathrm{m}$ sections on a sliding microtome. Prior to immunostaining, sections underwent antigen retrieval in $10 \mathrm{mM}$ sodium citrate, $\mathrm{pH} 6.0$ at $80^{\circ} \mathrm{C}$ for $2 \mathrm{~h}$. Sections were then washed in PBS and immunostained as previously described using rabbit polyclonal (\#G4171, MilliporeSigma) or mouse monoclonal anti-GCase antibodies (\#MAB7410, R\&D Systems) [50]. Sections were blocked in $10 \%$ normal goat serum, $1 \%$ milk, and $0.2 \%$ gelatin prior to overnight incubation with primary antibody diluted in $3 \%$ normal goat serum and $0.2 \%$ gelatin. After washing, sections were probed with species-matched secondary antibodies diluted in $3 \%$ normal goat serum and $0.2 \%$ gelatin. Sections were then washed and incubated with avidin-biotin complex (VectaStain Elite, Vector Laboratories). Immunostaining was detected by incubating with 3,3'-diaminobenzidene (MP Biomedicals) in $100 \mathrm{mM}$ Tris, pH 7.4. All antibody incubations and washes were conducted with PBS containing $0.5 \%$ Triton X-100. Initial quantification of GCase immunolabeling was performed on sections with no counterstain, but in follow-up studies sections were counterstained with either Cresyl violet (MilliporeSigma) or hematoxylin (Fisher Scientific). For fluorescent immunostaining, sections were co-stained with a rabbit monoclonal anti-NeuN antibody (\#ab177487, Abcam). GCase immunolabeling was detected with an AlexaFluor488 anti-mouse antibody (ThermoFisher Scientific), and NeuN immunolabeling was detected with an AlexaFluor594 anti-rabbit antibody (ThermoFisher Scientific). Fluorescently-labeled sections were stained with $1 \%$ Sudan Black (Acros Organics) to quench autofluorescence.

\section{Imaging and analysis}

Imaging and analysis of GCase-immunostained tissue was performed by investigators blinded to experimental group. Chromogenic GCase-immunostained tissue sections were imaged at $20 \mathrm{X}$ on a brightfield microscope (Nikon) and analyzed using ImageJ. For each patient, 23 20X fields of view were captured in cortical layer III. Total GCase immunoreactivity was assessed on sections with no counterstain by measuring the area falling within a uniform intensity threshold. In a follow-up study, sections were counterstained with hematoxylin. Hematoxylin (blue) and GCase (brown) labeling were deconvoluted, and neurons were defined by using Image)'s Analyze Particles feature to draw ROIs. These ROIs were then overlaid onto the GCase image to define neuronal GCase immunoreactivity.

Fluorescently-stained sections were imaged at $40 \mathrm{X}$ on a Nikon A1R confocal. For each patient 2-4 z-stacks of 
$25 \mu \mathrm{m}$ thickness were obtained using $0.5 \mu \mathrm{m}$ z-steps. Maximum intensity projections were made of both NeuN and GCase immunoreactivity. Neuronal ROIs were drawn using ImageJ's analyze particles feature on the NeuN images. These ROIs were overlaid onto the GCase images to measure the fluorescent intensity of each neuron.

\section{Cell culture and co-immunoprecipitation}

HEK-293 cells (\#CRL-1573, ATCC) were cultured in DMEM (Corning Life Sciences) with 10\% fetal bovine serum (Atlanta Biologicals), and 1\% penicillin/streptomycin (ThermoFisher) at $37{ }^{\circ} \mathrm{C}$ and $5 \% \mathrm{CO}_{2}$. Cells were transiently transfected with a plasmid expressing human $G B A 1$ with a C-terminal myc-flag tag (\#RC216061, Origene), and/or a construct expressing human progranulin with an $\mathrm{N}$ terminal HA tag inserted after the signal peptide in the previously described CIGW vector [4,60]. After $48 \mathrm{~h}$, the cells were harvested in lysis buffer $(50 \mathrm{mM}$ Tris, $150 \mathrm{mM} \mathrm{NaCl}$, 5 mM EDTA, 1\% Triton X-100, 0.1\% sodium deoxycholate) and centrifuged $10 \mathrm{~min}$ at $5000 \mathrm{x}$ g. HA-tagged progranulin was immunoprecipitated from $100 \mu \mathrm{g}$ of lysate protein using $2.5 \mu \mathrm{g}$ of anti-HA tag antibody (mouse monoclonal, \#sc-7392, Santa Cruz Biotechnology) as described above. Immunoprecipitates were blotted for Flag tag (mouse monoclonal, \#F3165, MilliporeSigma) to detect coimmunoprecipitated GCase, and for progranulin to confirm successful pull down of HA-tagged progranulin (rabbit polyclonal, \#40-3400, ThermoFisher).

\section{Proximity ligation assays}

HEK-293 cells were cultured on $12 \mathrm{~mm}$ No. 1 glass coverslips (Carolina Biological) coated with $0.1 \mathrm{mg} / \mathrm{mL}$ Poly-D-Lysine (MilliporeSigma) and $0.02 \mathrm{mg} / \mathrm{mL}$ laminin (MilliporeSigma), then transfected with $G B A$ myc-Flag and HA-GRN plasmids as described above. Forty-eight hours after transfection, cells were fixed in $4 \%$ paraformaldehyde and $4 \%$ sucrose. The coverslips were incubated overnight at $4{ }^{\circ} \mathrm{C}$ with anti-HA (rabbit monoclonal, \#3274, Cell Signaling Technologies) and anti-Flag (goat polyclonal, \#ab1257, Abcam) antibodies, and probed the next day with a Duolink proximity ligation kit (MilliporeSigma) with donkey anti-rabbit and donkey anti-goat probes using the manufacturer's protocol. All coverslips were imaged with an epifluorescent microscope (Nikon) at 60x.

\section{Lipidomics}

Levels of glucosylceramide isoforms and glucosylsphingosine were measured at the Lipidomics Shared Resource at the Medical University of South Carolina. Shavings from frozen tissue blocks were homogenized (lysate buffer: $0.25 \mathrm{M}$ sucrose, $25 \mathrm{mM} \mathrm{KCl,} 0.5 \mathrm{mM}$ EDTA, $50 \mathrm{mM}$ Tris, $\mathrm{pH} 7.4$ ), and protein content was determined by Bradford assay. Lipids were extracted from lysate containing $1 \mathrm{mg}$ of total protein, and were measured with high-performance liquid chromatography/mass spectrometry as previously described [8].

\section{AAV administration}

The effects of AAV-progranulin on GCase activity in $\mathrm{Grn}^{-/-}$mice were measured in ventral striatum samples from mice used in a previous study of AAV-progranulin [4]. A second group of mice was injected with AAVprogranulin or AAV-GFP by infusion in the medial prefrontal cortex as previously described [4]. These mice were treated at 3-6 months of age and euthanized for tissue collection 4 weeks later.

\section{Experimental design \& statistics}

Lysosomal enzyme activity, protein levels, and chromogenic immunostaining in patient samples were analyzed by $t$-test. The intensity of fluorescent GCase immunolabeling was analyzed by mixed-effects regression models with random effects intercept term blocking on subjects to account for the repeated measures. Linear mixed-models were used to compare mean intensities between groups while quantile regression was used to compare deciles. Levels of glucosylceramide isoforms were analyzed by MANOVA. Lysosomal enzyme activity in mice was analyzed by one-way ANOVA. Main effects of genotype were followed by Dunnett's posthoc test to compare $\mathrm{Grn}^{+/-}$and $\mathrm{Grn}^{-/-}$mice to wild-type. The effects of AAV-progranulin in ventral striatum samples were analyzed by two-way ANOVA with factors of genotype and virus. The effects of AAV-progranulin across multiple brain regions were analyzed by repeated-measures ANOVA with factors of genotype, virus, and brain region, followed by individual repeated measures ANOVA for each genotype with factors of virus and brain region. These twoway repeated measures ANOVA were followed by Sidak's post-hoc test to analyze the effect of virus within each brain region. MANOVA and three-way repeated measures ANOVA were performed with SPSS 24 (IBM), Mixedmodel regression was performed with $\mathrm{R}$ with additional utility from the lme4 and lqmm packages, and all other analyses were performed with Graphpad Prism 7 (GraphPad). For all analyses, two-tailed $p$ values were calculated, with $\alpha$ set at 0.05 .

\section{Results}

Increased HexA and decreased GCase activity patients with FTD-GRN

We hypothesized that progranulin insufficiency would impair the activity of sphingolipid-metabolizing enzymes in the brain. To test this hypothesis, we measured activity of $\beta$-galactosidase $(\beta-\mathrm{Gal})$, total $\beta$-hexosaminidase $(\beta$-Hex), $\beta$-hexosaminidase A (HexA), $\alpha$-galactosidase A (GLA), and $\beta$-glucocerebrosidase (GCase) in postmortem samples 

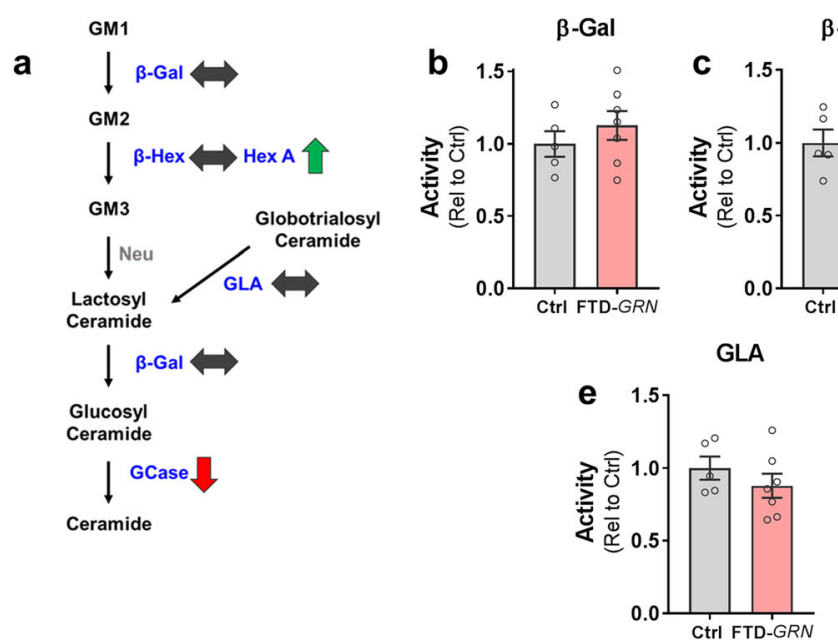

$\beta-$ Hex
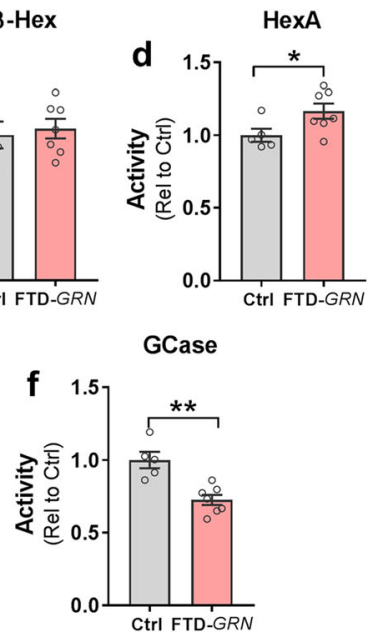

Fig. 1 Deficits in GCase Activity in Inferior Frontal Gyrus from Patients with FTD-GRN. Lysates from inferior frontal gyrus of controls and FTD-GRN patients were analyzed for activity of sphingolipid-metabolizing enzymes. a, Simplified diagram of metabolism of gangliosides, with a summary of observed phenotypes in FTD-GRN cases. Lipids are shown in black, with the enzymes that metabolize each lipid shown in blue. GM1, 2, and $3=\mathrm{GM} 1$, 2, and 3 ganglioside, $\beta$-Gal = $\beta$-galactosidase, $\beta$-Hex $=\beta$-Hexosaminidase, $H$ exA $=\beta$-Hexosaminidase A, GLA = a-galactosidase A, GCase $=\beta$ glucocerebrosidase, $\mathrm{Neu}=$ neuraminidase (activity not measured in this study). $\mathbf{b}-\mathbf{f}$, Enzymatic activity in FTD-GRN patient brains as measured by fluorogenic assays for $\mathbf{b}, \beta$-Gal, $\mathbf{c}, \beta$-Hex, $\mathbf{d}$, HexA, which was increased $(*=t$ test, $p=0.0474)$, $\mathbf{e}, \mathrm{GLA}$, and $\mathbf{f}$, GCase, which was decreased $(* *=t$ test, $p=0.0015) . n=5$ controls, 7 FTD-GRN

of inferior frontal gyrus from controls and patients with FTD-GRN (Fig. 1a). We detected an increase in HexA activity (Fig. 1d) and a reduction in GCase activity (Fig. 1f), but no change in $\beta$-Gal, GLA, or total $\beta$-Hex activity in FTD-GRN patients relative to controls.

This pattern of changes in enzyme activity was not consistent with a generalized impairment of saposindependent enzymes [58], as $\beta$-Gal and GLA require saposin B for optimal activity but were unchanged in FTD-GRN patients. Instead, the selective changes in HexA and GCase activity in FTD-GRN patients may be related to their reported interaction with progranulin $[14,29,30]$. The opposite directionality of the changes in HexA and GCase was somewhat surprising. Progranulin may facilitate the processing and lysosomal trafficking of both enzymes, which could result in reduced activity under progranulin-insufficient conditions [14, $29,30]$. However, we and others have observed increased HexA activity in brains from progranulin-insufficient mice $[3,33,61,62]$, perhaps indicating cell-type-specific effects of progranulin-insufficiency on enzyme function. To gain further insight into the mechanisms underlying the altered HexA and GCase activity, we investigated how the changes in enzyme activity related to enzyme levels in brains of FTD-GRN patients.

\section{Increased HexA protein levels in patients with FTD-GRN}

We observed elevated HexA protein levels in FTD-GRN patients relative to controls (Additional file 1: Figure S1a). This increase in HexA levels is consistent with a general increase in lysosomal proteins in FTD-GRN patients [25] and progranulin-insufficient mice [24, 25, 33, 61, 62]. Consistent with these prior reports, we also observed elevated LAMP-1 and LAMP-2 levels, and a trend for increased mature cathepsin D levels in FTD-GRN patients (Additional file 1: Figure S1). Given the general increase in lysosomal proteins in FTD-GRN patients, the increase in HexA and other lysosomal proteins may be a compensatory response to lysosomal dysfunction caused by progranulin haploinsufficiency.

\section{Abnormal GCase processing in FTD-GRN}

We next assessed GCase protein levels by immunoblot with two GCase antibodies, both of which revealed lower levels of mature GCase protein in patients with FTDGRN than controls (Fig. 2a-c). This reduction in GCase differed distinctly from the potentially compensatory increases in HexA and other lysosomal proteins in the same samples. Immunoblots with a rabbit polyclonal anti-GCase antibody revealed an abnormal lower molecular weight band (Fig. 2a) in all but one of the patients with FTD-GRN (the exception being case \#7 in Table 1, which was unique as further discussed below). We hypothesized that this band might be composed of incompletely glycosylated GCase, indicative of abnormal GCase processing. Under this hypothesis, the opposite directionality of GCase relative to other lysosomal proteins would be due to impairment of GCase processing that prevents a compensatory increase in GCase, such as we have previously observed in $\mathrm{Grn}^{+/-}$mice [3].

To test this hypothesis, we treated tissue lysates with the deglycosylating enzymes Peptide- $N$-glycosidase F 

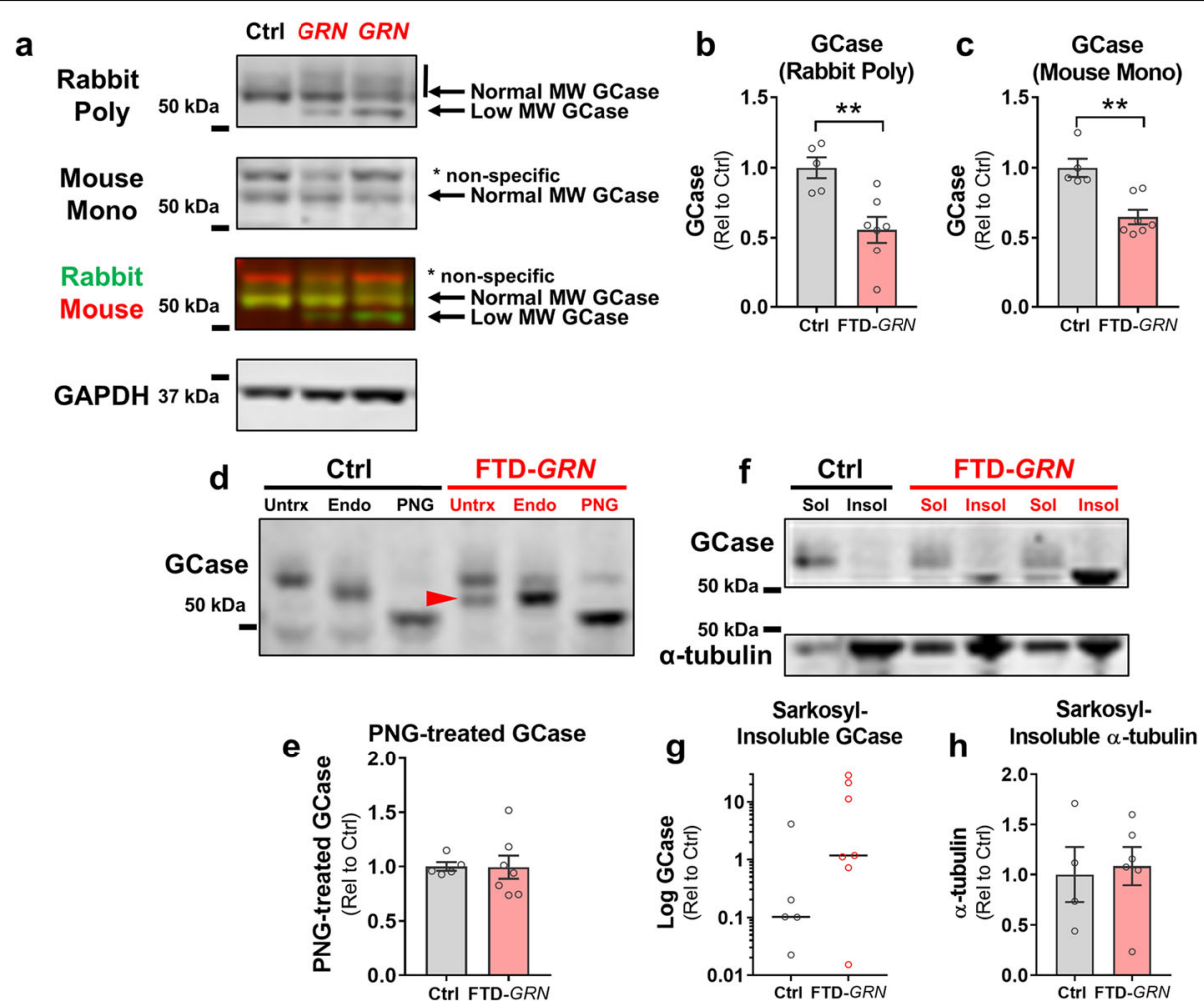

Fig. 2 Lower Levels of Mature GCase Protein and Accumulation of Incompletely Glycosylated GCase in Brains from FTD-GRN Patients. a-c, Lysates of inferior frontal gyrus from FTD-GRN cases had lower levels of normal molecular-weight GCase protein than controls as detected by a rabbit polyclonal anti-GCase antibody (b, $t$ test, $p=0.0059)$, and a mouse monoclonal anti-GCase antibody (c, $t$ test, $p=0.0017)$. The polyclonal antibody also detected a lower molecular weight band that was present in all but one FTD-GRN case, but rarely in controls. $\mathbf{d}$, To determine whether this lower molecular weight band could represent incompletely glycosylated GCase, lysates were treated with Endo H or PNGase F. The lowermolecular weight GCase band (red arrowhead) was approximately the same molecular weight as Endo H-treated GCase. Complete removal of glycosylation with PNGase F collapsed the multiple GCase bands into one band just over 50 kDa, indicating that the low-molecular weight form of GCase detected by the polyclonal antibody may consist of incompletely glycosylated GCase. The higher molecular weight band detected by the mouse monoclonal antibody was determined to be non-specific because it did not shift with PNGase F treatment (data not shown). e, Unlike normal molecular weight GCase, there were no group differences in deglycosylated (PNGase F-treated) GCase ( $t$ test, $p=0.9594$ ), showing that while FTD-GRN brains contain less normal molecular weight, active GCase than controls, they have similar total levels of GCase protein. f, The low-molecular weight form of GCase accumulated in the sarkosyl-insoluble fraction of FTD-GRN brains, while normal molecular weight GCase was only detectable in the soluble fractions. Levels of sarkosyl-insoluble GCase did not statistically differ between controls and FTD-GRN patients (g. Mann-Whitney test, $p=0.1490$ ), but the insoluble band was detectable in 6/7 FTD-GRN patients, but only reliably detectable in 1/5 controls. This stands in contrast to a-tubulin (f, $\mathbf{h})$, which did not differ between groups. Levels of insoluble GCase were very high in some FTD-GRN patients, so data in $\mathbf{g}$ are shown in log scale. $n=5$ controls, and 7 FTD-GRN. ${ }^{*}=p<0.05$ and ${ }^{* *}=p<0.1$ by Tukey's post-hoc test. GCase $=\beta$ glucocerebrosidase, Endo = Endoglycosidase $\mathrm{H}, \mathrm{PNG}=$ PNGase $\mathrm{F}$

(PNGase F) or Endoglycosidase H (Endo H) and immunoblotted the reaction products with the polyclonal GCase antibody (Fig. 2d). PNGase F removes most Nlinked glycans from glycosylated proteins, resulting in a shift to lower molecular weight in SDS-PAGE. With PNGase F treatment, both the normal- and lower molecular weight GCase bands shifted to a single band just above $50 \mathrm{kDa}$, confirming that the lower molecular weight band in FTD-GRN patients was composed of incompletely glycosylated GCase. There were no group differences in the density of the completely deglycosylated GCase band (Fig. 2e), showing that brains from FTD-GRN patients contain a similar amount of total
GCase protein as controls, but less fully glycosylated, active GCase (Figs. 1f and 2a-c).

In contrast to PNGase F, Endo $\mathrm{H}$ is only capable of removing immature glycans that have not undergone final processing in the Golgi apparatus. Thus, increased Endo $\mathrm{H}$-sensitivity is an indicator that a protein may have been misfolded and retained in the endoplasmic reticulum. Neither the normal or lower molecular weight GCase bands were fully Endo $\mathrm{H}$ sensitive in FTD-GRN samples (Fig. 2d, defined as shifting to the completely deglycosylated band), though Endo $\mathrm{H}$ treatment produced a small shift in the mature GCase band in all samples, including controls. The lower molecular 
weight GCase band seen in FTD-GRN (red arrowhead in Fig. 2d) was roughly the same size as Endo $\mathrm{H}$-treated GCase, consistent with an incomplete glycosylation pattern. Taken together, the PNGase $\mathrm{F}$ and Endo $\mathrm{H}$ data indicate that impaired GCase activity in FTD-GRN patients is due to abnormal GCase processing with incomplete glycosylation.

As a positive control for these experiments, we analyzed GCase immunoblots from fibroblasts carrying the L444P mutation in GBA (the gene encoding GCase) which causes the lysosomal storage disorder Gaucher disease in homozygous carriers [27]. The GBA L444P mutation produces misfolded GCase that is retained in the endoplasmic reticulum and is incompletely glycosylated [7]. We observed nearly complete loss of mature, glycosylated GCase in homozygous L444P fibroblasts and accumulation of lower molecular weight, incompletely glycosylated GCase in heterozygous and homozygous L444P fibroblasts (Additional file 2: Figure S2), thus confirming that the polyclonal GCase antibody can detect both fully and incompletely processed GCase.

To further investigate abnormal GCase processing, we measured GCase in the soluble and insoluble fractions of brains from controls and FTD-GRN patients using a standard sarkosyl-soluble/insoluble fractionation protocol [17] (Fig. 2f-h). We detected normal molecular weight GCase primarily in the sarkosyl-soluble fraction. However, the lower molecular weight, incompletely glycosylated form of GCase was enriched in the sarkosylinsoluble fraction of 6 of the 7 FTD-GRN brains, indicating accumulation of insoluble, immature GCase. In contrast, only one of the control patients accumulated readily detectable amounts of insoluble GCase (Fig. 2g, Additional file 3: Figure S3a).

\section{A unique GRN carrier without a clinical or pathological FTD spectrum diagnosis}

Only one of the seven patients with a GRN mutation completely lacked the abnormal low-molecular weight GCase band (Additional file 3: Figure S3a). This patient also had the least severe deficits in GCase activity and protein levels, which were within the normal range (Additional file 3: Figure S3b-d). Interestingly, this case (\#7 in Table 1) was also clinically and pathologically unique. It was the only GRN case without a primary clinical diagnosis of FTD, having features most consistent with dementia with Lewy bodies (DLB). Consistent with that clinical diagnosis, this patient had a primary neuropathological diagnosis of diffuse neocortical Lewy body disease, with only the beginnings of FTLD-TDP type A pathology (Table 1, Additional file 3: Figure S3e). This patient thus represents a rare case of a GRN carrier coming to autopsy before FTD symptoms or robust FTLD-TDP pathology manifested, having died from
DLB. While this is a single case, it is notable that the only FTD-GRN patient in which GCase processing deficits were absent also had the mildest TDP-43 pathology.

\section{Loss of neuronal GCase in FTD-GRN}

We next conducted GCase immunostaining to assess which cell types are affected by the loss of GCase in FTD-GRN patients. We immunostained sections of inferior frontal gyrus with the rabbit polyclonal GCase antibody used in the preceding experiments, as well as a second mouse monoclonal GCase antibody. In a preliminary study with L444P Gaucher fibroblasts, we confirmed that the rabbit polyclonal antibody detected both mature, fully glycosylated and immature, incompletely glycosylated GCase, but the mouse monoclonal antibody selectively detected mature, fully glycosylated GCase, not recognizing the lower molecular weight band (Fig. 3a). Immunostaining of control sections revealed similar patterns of immunolabeling with each antibody (Fig. 3b, d), with particularly strong labeling of layer III pyramidal neurons. We therefore measured GCase immunolabeling in 20X images of layer III. Consistent with western blot data (Fig. 2d), FTD-GRN patients did not have a significant reduction in total GCase immunolabeling with the rabbit polyclonal antibody (Fig. 3b, c). In contrast, the mouse monoclonal antibody selective for mature GCase revealed a clear reduction in mature.

GCase immunolabeling (Fig. 3d, e). With both antibodies, there appeared to be a loss of strongly GCaseimmunolabeled layer III pyramidal neurons, which is consistent with layer III neuronal loss in FTD. We therefore performed additional experiments to determine if the GCase deficits in FTD-GRN patients were driven by neuronal loss.

To determine if the loss of neuronal GCase in FTDGRN patients was simply a consequence of neuronal loss, we employed two approaches to assess GCase in surviving neurons of FTD-GRN patients. First, we used hematoxylin counterstaining to identify pyramidal neurons in sections stained for mature GCase with the mouse monoclonal antibody (Fig. 4a). As expected, FTD-GRN patients had fewer hematoxylin-labeled neurons than controls, resulting in a lower total neuronal area (Fig. 4b). ROIs were drawn around hematoxylinlabeled neurons to measure neuronal GCase immunolabeling, revealing that FTD-GRN patients had less neuronal GCase immunolabeling than controls (Fig. 4c). This reduced neuronal GCase immunolabeling survived correction for the reduced neuronal area of FTD-GRN patients (Fig. 4d). This indicates that while neuronal loss likely contributes to some loss of GCase activity in FTDGRN patients, the surviving neurons still have less GCase immunolabeling than controls.

Second, we assessed neuronal GCase immunolabeling with fluorescent microscopy. Neurons were identified by 


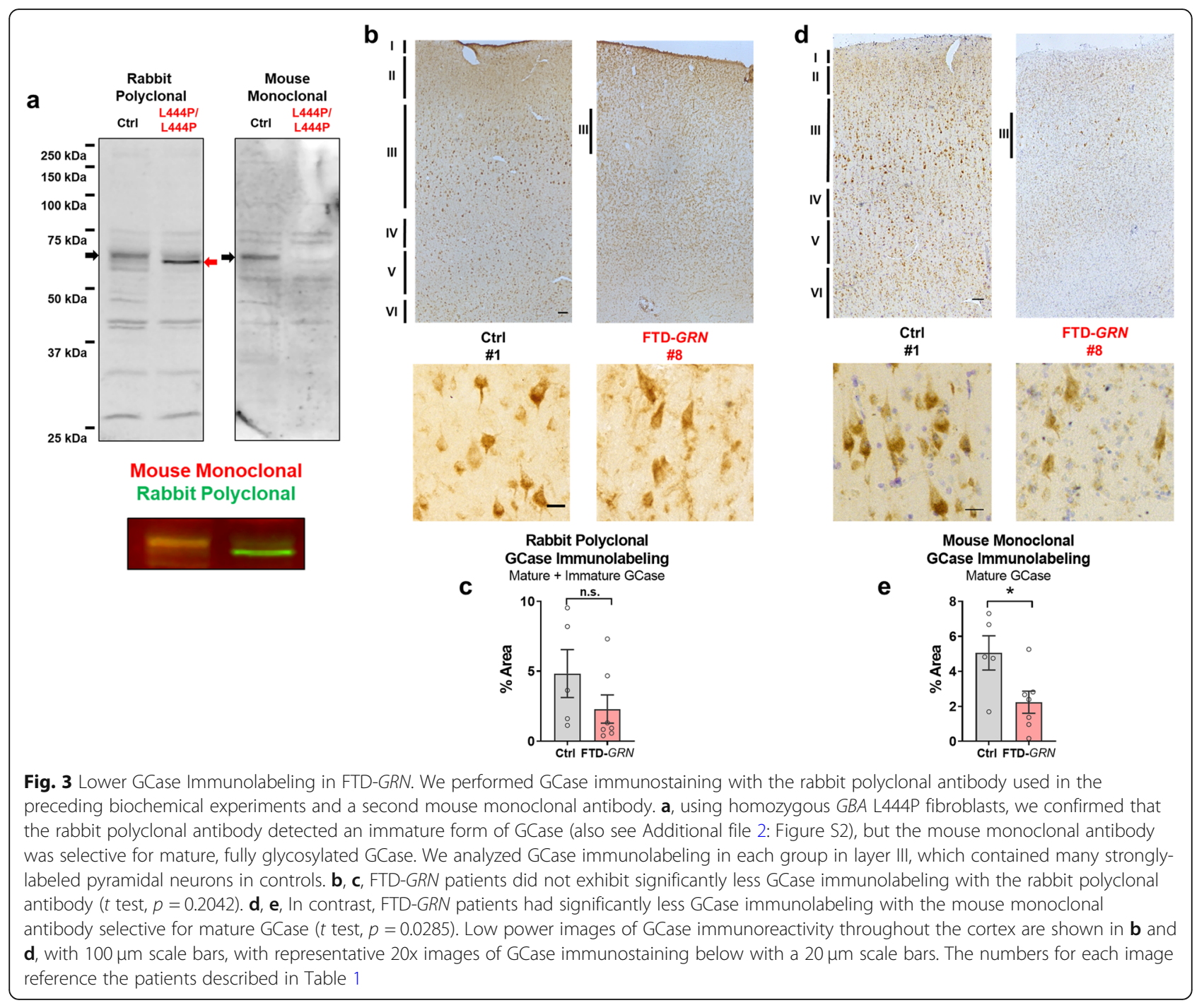

NeuN immunoreactivity, which labeled both the nucleus (strongly) and soma (faintly) of pyramidal neurons (Fig. 4e) [40]. We measured the mean intensity of GCase immunolabeling in ROIs drawn around NeuN-positive neurons and obtained measurements from 80 to 147 neurons per patient from 5 controls and 11-132 neurons per patient from 6 FTD-GRN patients. Initial analyses of these data revealed lower GCase immunolabeling in FTD-GRN patients than controls, both by comparing the average intensity of all neurons measured ( $t$ test, $p<0.001$ ) and by comparing the distribution of GCase intensity between neurons from controls and FTD-GRN patients (Fig. 4f, g, KolmogorovSmirnov test, $p<0.0001$ ). We then conducted a follow-up analysis to determine if this difference was driven by true group differences, instead of by the greater number of neurons detected in controls or by variability in the neurons from specific patients. This subsequent analysis was performed with a mixed-model regression to account for serial correlation within subjects, then with undersampling as a sensitivity assessment to limit the influence of any one patient. This mixed-model analysis confirmed significant distribution-based differences in fluorescent intensity between groups, with the control distribution being significantly skewed toward higher intensity relative to FTDGRN patients (Fig. 4f, g). Undersampling with a limit of no more than 40 neurons per patient yielded similar results with no change in statistical significance (Additional file 4: Figure S4). These data show that FTDGRN patients have less neuronal GCase than controls, and that this decrease cannot be explained entirely by neuronal loss, but is also caused by a reduction in the amount of mature GCase per neuron.

\section{FTD-GRN patients do not accumulate GCase substrates}

Given the loss of GCase activity in the brain, we tested whether FTD-GRN patients accumulated the GCase substrates glucosylceramide (GlcCer) and glucosylsphingosine 


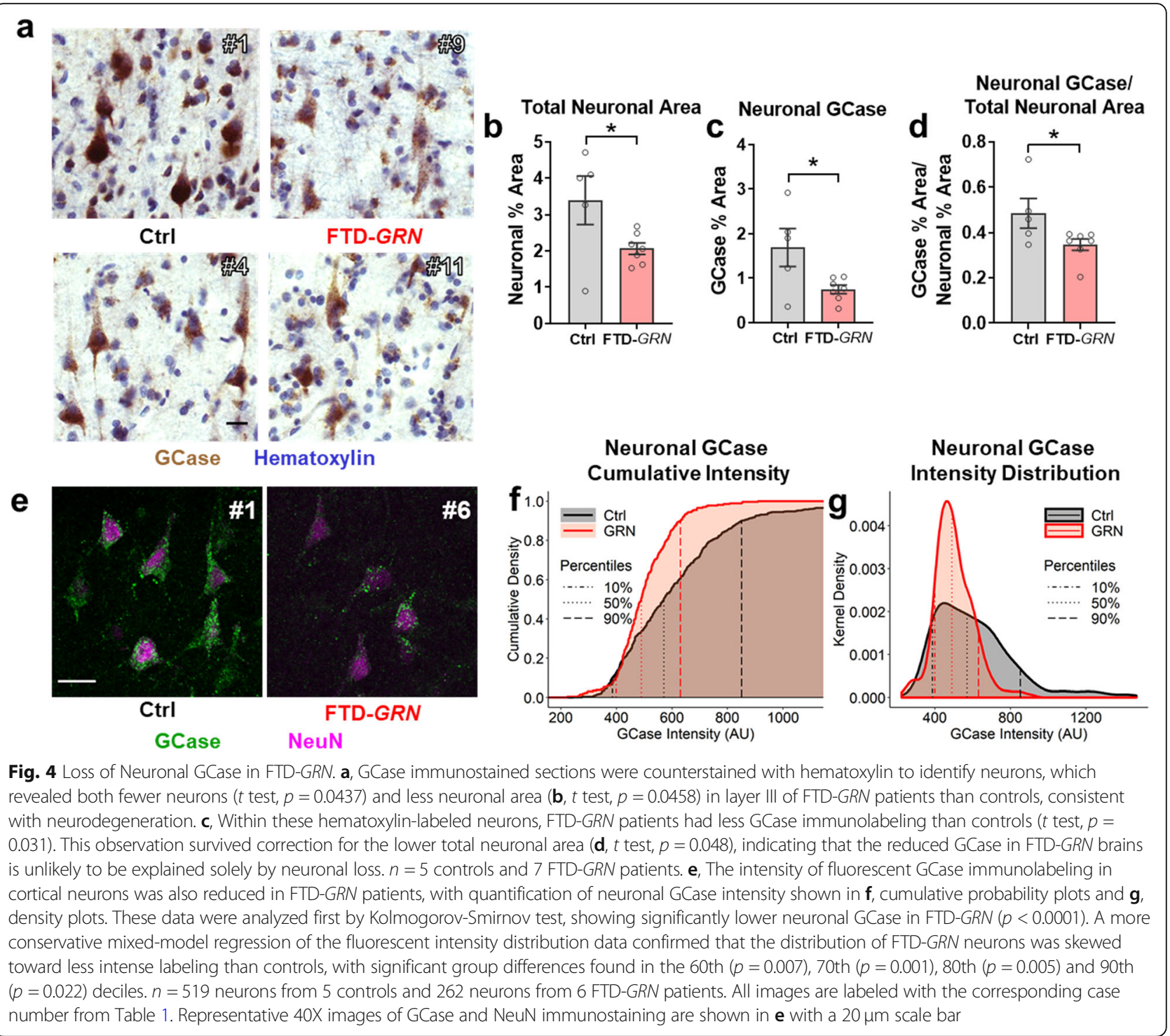

(GlcSph), which accumulate in the brain of patients with neuronopathic Gaucher disease due to severe GCase deficiency $[46,49]$. We did not observe accumulation of any GlcCer isoforms (Fig. 5a), total GlcCer (Fig. 5b), or GlcSph (Fig. 5c) in FTD-GRN patients. This is consistent with data from heterozygous $G B A$ mutation carriers $[9,22]$, and indicates that the remaining GCase activity is sufficient to prevent accumulation of these lipids.

\section{Progranulin and GCase interact}

Progranulin has recently been reported to interact with GCase and facilitate proper GCase processing and trafficking to the lysosome $[29,30]$. Our findings are consistent with these data, so we next sought to confirm that progranulin interacts with GCase. We co-transfected HEK-293 cells with constructs expressing HA-tagged human progranulin (HA-GRN) and/or myc-Flag-tagged human GCase (GBA-myc-Flag), and immunoprecipitated human progranulin from lysates of these cells with an HA-tag antibody. Consistent with a prior report [29], we found that GCase co-immunoprecipitated with progranulin (Fig. 6a).

We next performed in situ analysis of progranulin and GCase interaction by proximity ligation assay (PLA). HEK-293 cells were transfected with HA-GRN and GBA-myc-Flag constructs and processed for PLA $48 \mathrm{~h}$ later. We detected abundant PLA signal in cells transfected with both constructs and probed with HA and Flag antibodies (Fig. 6b). We detected essentially no PLA signal in negative control cells transfected with only one of the constructs, or when omitting the primary antibodies on cells transfected with both constructs (Fig. 6c). 


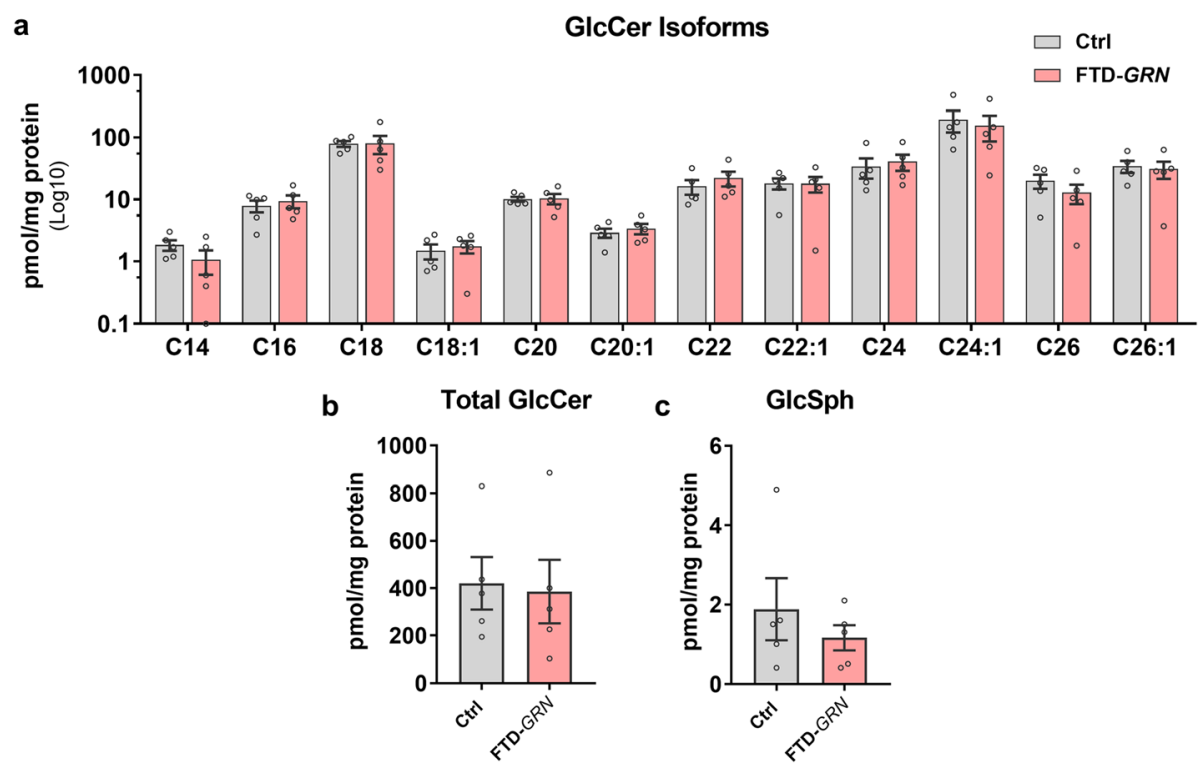

Fig. 5 Brains from FTD-GRN Patients Do Not Accumulate Glucosylceramide or Glucosylsphingosine. Lipids were extracted from lysates of inferior frontal gyrus of control and FTD-GRN patients and analyzed by high performance liquid chromatography/mass spectrometry. No group differences were detected in glucosylceramide isoforms ( $\mathbf{a}$, MANOVA effect of group, $p=0.954)$, total levels of glucosylceramide $(\mathbf{b}, t$ test, $p=$ 0.8470), or glucosylsphingosine (c, $t$ test, $p=0.4199$ ). $n=5$ controls and 5 FTD-GRN. GlcCer = glucosylceramide, GlcSph = glucosylsphingosine

\section{GCase activity deficits in $\mathrm{Grn}^{-/-}$mice}

To assess the effects of progranulin insufficiency on GCase activity independent of neurodegeneration in an experimentally manipulable model, we measured activity of GCase and other sphingolipid-metabolizing enzymes in frontal cortical lysates from 7 to 10-month-old progranulin-insufficient mice. Except for GCase, $\mathrm{Grn}^{-1-}$ mice had elevated activity of every enzyme measured ( $\beta-G a l, \beta-H e x$ (total), HexA, and GLA, Fig. 7b-e). Similar to FTD-GRN patients, $\mathrm{Grn}^{-/-}$mice had reduced GCase activity (Fig. 7f). We did not observe any significant changes in enzyme activity in $\mathrm{Grn}^{+/-}$mice, although we previously observed that older $\mathrm{Grn}^{+/-}$mice (12-20 months) exhibit elevated HexA and GCase activity [3]. These data indicate that progranulin insufficiency impairs cortical GCase activity in the absence of neuronal loss and indicate that GCase requires progranulin for normal activity in the brain.

\section{Progranulin gene therapy normalizes GCase activity in $\mathrm{Grn}^{-/-}$mice}

Since progranulin insufficiency impairs GCase activity in the brain, we hypothesized that restoration of progranulin would normalize GCase activity. We have previously shown that AAV-mediated restoration of progranulin to $\mathrm{Grn}^{-/-}$mice reduces lipofuscinosis and normalizes elevated cathepsin D activity [4]. We therefore analyzed GCase activity in tissue samples from the mice in our previous study [4] to determine if restoration of progranulin could normalize GCase deficits. These mice were treated with AAV-progranulin (AAV-Grn) or AAV-GFP by infusion into the medial prefrontal cortex at 10-12 months of age and euthanized 8-10 weeks later for brain collection. We began our investigation of GCase activity with ventral striatum lysates in which we previously observed normalization of cathepsin D activity [4]. We observed a genotype-specific effect of AAV-Grn. AAV-Grn boosted GCase activity in $\mathrm{Grn}^{-/-}$mice (Fig. $7 \mathrm{~g}$ ), showing that restoration of progranulin can improve GCase deficits. In contrast, AAV-Grn suppressed GCase activity in wild-type mice. This was somewhat surprising but consistent with our prior observations of reduced cathepsin D activity in AAV-Grn-treated wild-type mice [4].

To confirm this finding, we analyzed tissue samples from a second group of mice treated with AAV-Grn by infusion into the medial prefrontal cortex at 3-6 months of age and euthanized for analysis 4 weeks later (average age at euthanasia $=5.9$ months). Similar to the first cohort, we found that restoration of progranulin with AAV-Grn gene therapy in $\mathrm{Grn}^{-/-}$mice normalized GCase deficits across multiple brain regions (Fig. 7h).

\section{Discussion}

This study shows that progranulin insufficiency impairs GCase activity in the frontal cortex of patients with FTDGRN. GCase was the only sphingolipid-metabolizing enzyme among those analyzed in this study to show impaired activity in FTD-GRN patients, suggesting a specific GCase deficit, rather than a general deficit in sphingolipid metabolism. We found evidence in FTDGRN patients for abnormal GCase processing, with 

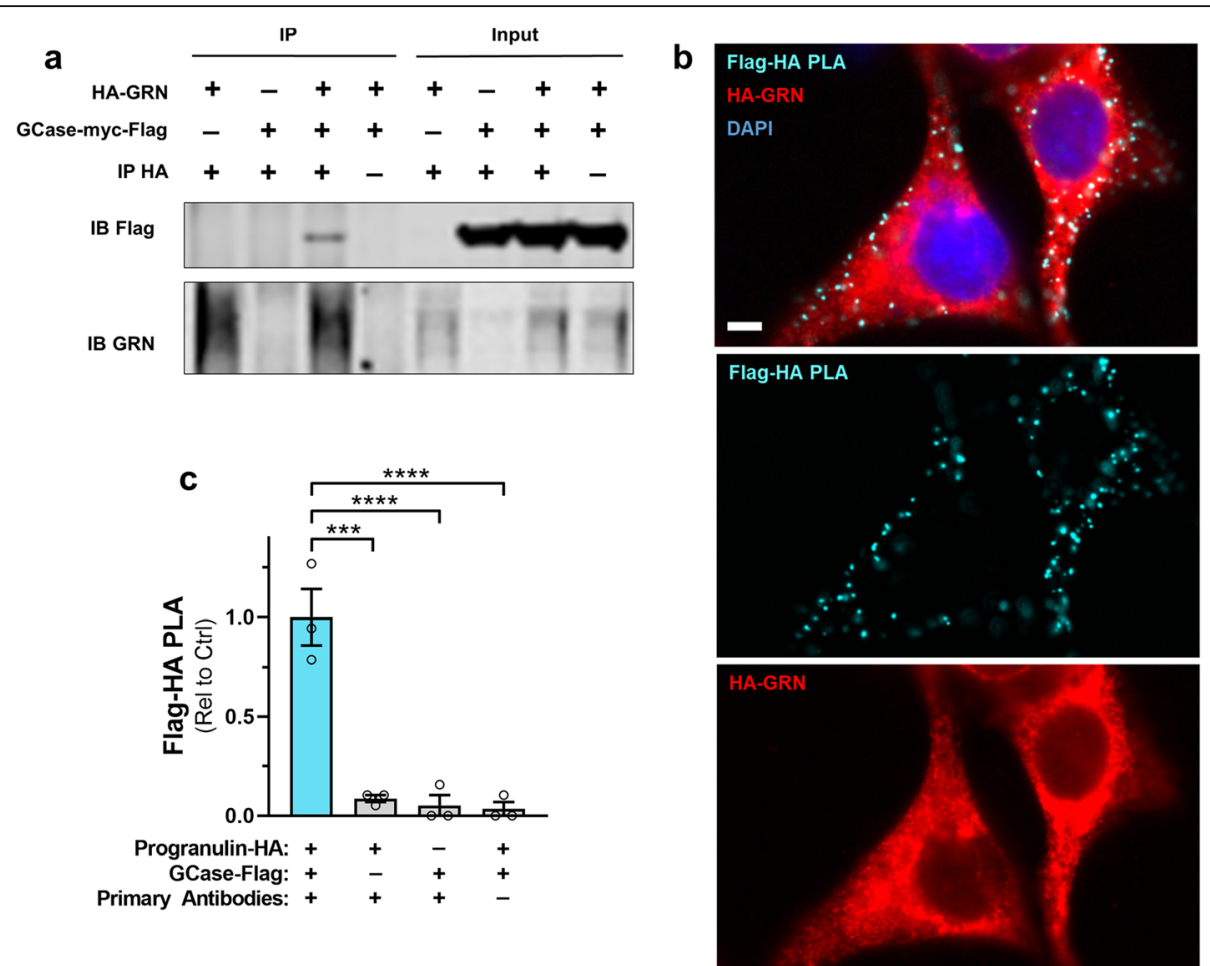

Fig. 6 Progranulin Interacts with GCase. HEK-293 cells were co-transfected with constructs expressing HA-tagged human progranulin and/or myc-flagtagged human GCase. HA-tagged progranulin was then immunoprecipitated from cell lysates with an anti-HA antibody. a, Flag-tagged GCase coimmunoprecipitated with progranulin, indicating interaction of the two proteins. $\mathbf{b}$, Consistent with the co-immunoprecipitation of GCase with progranulin, we detected strong proximity ligation (PLA) signal in HEK-293 cells co-transfected with human progranulin and human GCase constructs. c, The specificity of the Flag-HA PLA signal was confirmed by the presence of significantly more PLA puncta from cells co-transfected with the progranulin-HA and GCase-Flag constructs than in cells transfected with only one of the constructs, or from cells that underwent PLA in the absence of the HA and Flag antibodies (ANOVA effect of experimental condition, $p<0.00011^{* * *}=p<0.001$ and ${ }^{* * * *}=p<0.0001$ by Dunnett's post-hoc test). The scale bars represents $5 \mu \mathrm{m}$. GCase $=\beta$-glucocerebrosidase, $\mathrm{GRN}=$ progranulin, PLA $=$ proximity ligation assay

incomplete glycosylation and accumulation in the sarkosyl-insoluble fraction. GCase impairment in FTDGRN patients is likely the direct result of progranulin insufficiency, as $\mathrm{Grn}^{-/-}$mice also exhibited impaired GCase activity that was normalized by restoring progranulin with AAV-Grn gene therapy.

Brains from FTD-GRN patients accumulate lysosomal proteins, possibly due to underlying lysosomal dysfunction [25], and this study indicates that GCase deficits may be a component of the underlying lysosomal dysfunction. These GCase deficits may be caused by impaired GCase processing due to progranulin insufficiency. This work adds to prior reports that progranulin interacts with GCase [29, 30], and recent reports of reduced GCase activity in brains from $\mathrm{Grn}^{-/-}$ mice [72] and iPSC-derived neurons from GRN mutation carriers [65], further supporting the requirement of progranulin for normal GCase activity in the brain.

Regulation of lysosomal enzyme activity may be a key function of progranulin. Progranulin also regulates the activity of cathepsin D [6, 11, 12, 64, 71] and HexA [14]. For both cathepsin D and HexA, we and others have observed potentially compensatory increases in expression in FTD-GRN patients [25] and progranulininsufficient mice $[3,24,25,33,61,62]$ that stands in contrast to the GCase deficits reported in the present study. Interestingly, we also observed increased GCase activity in a prior study of $\mathrm{Grn}^{+/-}$mice [3]. This contrast may be explained by a GCase processing deficit that emerges when progranulin levels fall below a certain threshold. Progranulin-insufficient cells may compensate for impaired HexA and CatD activity by increasing HexA and CatD expression, but may be unable to compensate for impaired GCase activity due to impaired GCase processing.

The role of impaired GCase activity in FTD-GRN pathogenesis will be an important topic for future investigation. It is notable that the clinical spectrum of patients with GRN mutations is quite different from that of patients with GBA mutations. Homozygous GRN mutation carriers develop the lysosomal storage disorder NCL [2, 31, 59], and heterozygous carriers typically develop dominantly inherited FTD $[5,16]$, though some develop other disorders such as Alzheimer's disease, 


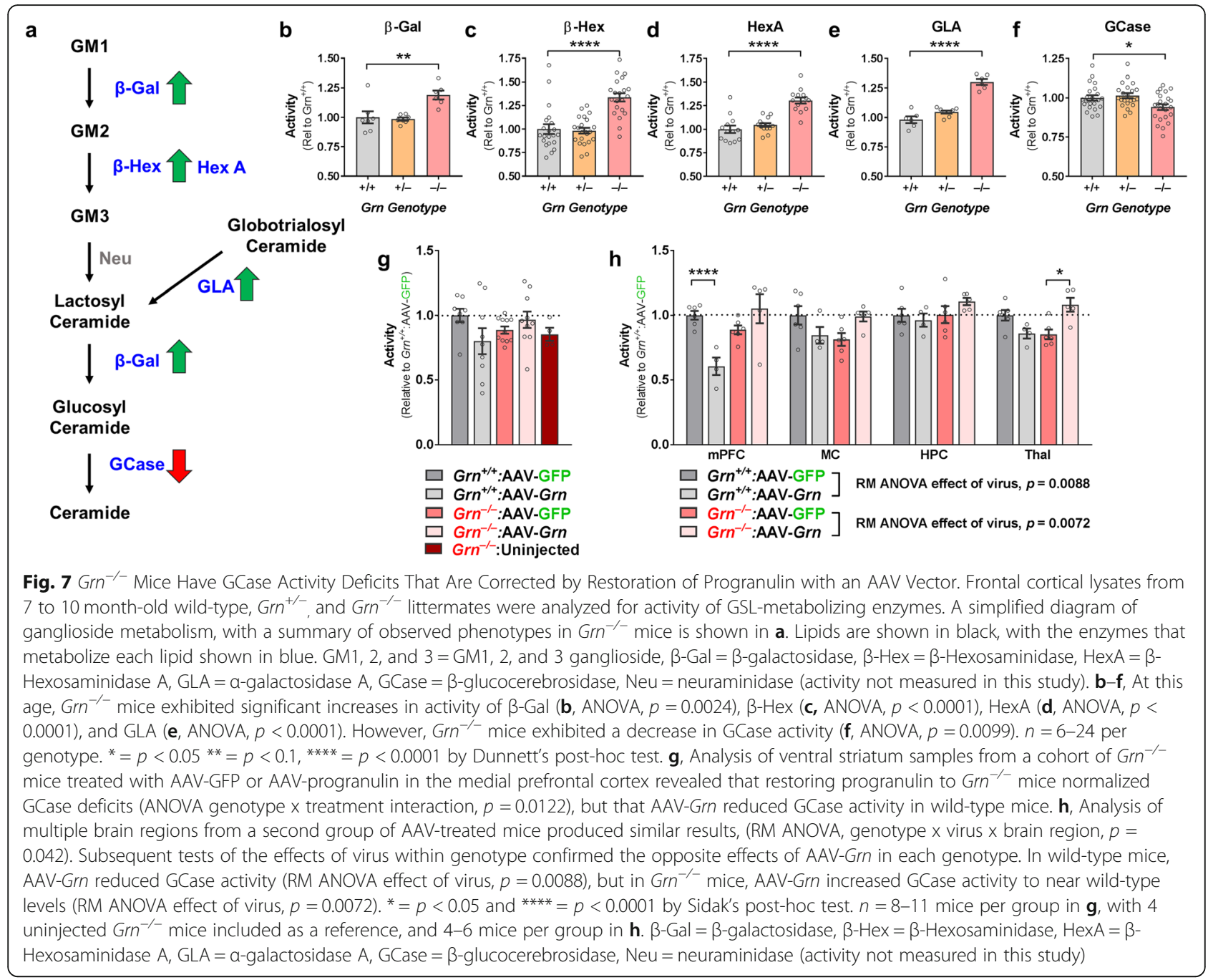

Parkinson's disease (PD), or DLB [10, 32, 56, 68]. In contrast, homozygous $G B A$ mutation carriers develop the lysosomal storage disorder Gaucher disease [26], and heterozygous carriers are at increased risk for PD and DLB $[1,42,48]$. PD and DLB patients without GBA mutations also exhibit GCase activity deficits in certain brain regions [15, 21, 39, 55], perhaps due to impairment of GCase activity by $\alpha$-synuclein [38]. Available data indicate that $G B A$ mutations do not increase risk for $\mathrm{AD}$ [63]. There is even less data on the influence of $G B A$ mutations on FTD. One study reported increased incidence of $G B A$ mutations in patients with corticobasal syndrome, but not other FTD subtypes [51]. Based on available data on progranulin's role in the lysosome, it seems possible that GCase deficits are one of several lysosomal deficits in GRN mutation carriers that contribute to disease. Defining progranulin's lysosomal interactome and the lysosomal deficits induced by progranulin insufficiency may help clarify the role of GCase deficits in FTD-GRN pathogenesis.
$G B A$ mutations are a major risk factor for PD and DLB $[1,42,48]$, so the impairment of GCase activity in FTD-GRN patients and $\mathrm{Grn}^{-/}$mice raises the question of whether GRN mutations or variants may also increase PD and DLB risk. GRN mutation carriers occasionally develop PD or DLB $[10,32,56,68]$, though they usually develop an FTD syndrome with TDP-43 pathology. Genetic studies testing for association of GRN variants with PD have produced mixed results [13, 28, 34, 47], though a preprint report of a large genome-wide association study has identified GRN as a risk gene for PD [41]. Interestingly, PD patients have lower circulating progranulin levels than controls [34]. Gaucher disease patients also have lower levels of serum progranulin than controls and have higher frequencies of GRN gene variants associated with lower progranulin levels [30]. In mouse models, progranulin is protective against dopaminergic neuronal loss due to MPTP $[37,66]$. This protection has been associated with progranulin's anti-inflammatory effects. However, 
it is possible that progranulin's interaction with GCase could play a role, as both $\mathrm{Grn}^{-/-}$mice and $\mathrm{Gba}^{+/ L 444 P}$ mice are more sensitive than wild-type mice to MPTPinduced dopaminergic neuronal loss [37, 70]. Thus, while current data on a role for progranulin in PD or DLB are sparse, this may be an interesting topic for future study.

The GCase deficits in $\mathrm{Grn}^{-/-}$mice show that progranulin insufficiency alone modestly impairs GCase activity in the brain, but we also obtained evidence that disease state may influence GCase activity in GRN mutation carriers. It is quite rare for a GRN mutation carrier to come to autopsy before developing FTD, as we observed in one case (\#7 in Table 1). In this case, which had only the beginnings of FTLD-TDP type A pathology (Additional file 3: Figure S3f), we did not observe the GCase abnormalities that were present in GRN cases with FTD-spectrum disorders and FTLD-TDP type A pathology: GCase activity (Additional file 3: Figure S3c) and GCase protein levels (Additional file 3: Figure S3d,e) were within the range of controls, and the low molecular weight GCase band was not observed in either soluble or insoluble fractions (Additional file 3: Figure S3a, b). Interestingly, this patient had a synucleinopathy, with a DLB clinical syndrome and Lewy body disease pathology (Table 1). Synucleinopathies including PD and DLB have been associated with GCase abnormalities, particularly in the substantia nigra $[15,21,39,55]$, so one might have expected to see GCase abnormalities even in the absence of significant FTD or FTLD pathology. However, patients with PD and DLB do not typically exhibit GCase deficits in the frontal cortex [15, 21, 39, 55]. Thus, the lack of GCase deficits in this case are consistent with data on patients with DLB. Although it is a single case, if confirmed in future studies, these observations would suggest that the GCase abnormalities we observed correlate with onset of dysfunction.

\section{Conclusions}

In summary, these data expand our knowledge of the lysosomal dysfunction induced by progranulin insufficiency in the brain. We have shown that progranulin insufficiency impairs GCase activity in the brain, likely by disrupting GCase processing, and that restoration of progranulin corrects these activity deficits in $\mathrm{Grn}^{-/-}$ mice. Future studies will investigate the role of these GCase deficits in FTD pathogenesis.

\section{Supplementary information}

Supplementary information accompanies this paper at https://doi.org/10 1186/s40478-019-0872-6.

Additional file 1: Figure S1. Elevated HexA, LAMP-1, and LAMP-2 in Inferior Frontal Gyrus from FTD-GRN Patients

Additional file 2: Figure S2. Representative GCase Blots from Gaucher Disease Fibroblasts
Additional file 3: Figure S3. Absence of Low-molecular Weight GCase and Lack of GCase Deficits in a GRN Carrier with Lewy Body Disease

Additional file 4: Figure S4. Undersampled Intensity Data

\section{Abbreviations}

AAV: adeno-associated virus; AD: Alzheimer's disease; bvFTD: behavioral variant frontotemporal dementia; CBS: corticobasal syndrome; DLB: dementia with Lewy bodies; FTD: frontotemporal dementia; GCase: $\beta$ glucocerebrosidase; GLA: a-galactosidase A; Grn: progranulin; GSL: glycosphingolipid; HexA: $\beta$-Hexosaminidase A; NCL: neuronal ceroid lipofuscinosis; Neu: neuraminidase; nfPPA: nonfluent variant primary progressive aphasia; PD: Parkinson disease; PLA: proximity ligation assay; PMI: postmortem interval; $\beta$-Gal: $\beta$-galactosidase; $\beta$-Hex: $\beta$-Hexosaminidase

\section{Acknowledgements}

We thank the patients and their families for their contributions to this work. We thank James Black and Miriam Roberson for help with mouse breeding and colony management, and John Shacka for assistance with enzyme activity assays. We thank Robert Farese, Jr. for providing $\mathrm{Grn}^{-/-}$mice.

\section{Authors' contributions}

AEA and EDR conceived the study. AEA, JRR, NRB, SNK, and MQH performed the experiments. ALN, SS, LTG, BLM, and WWS characterized the patients, made neuropathological diagnoses, and provided brain samples. EMR provided GBA genotyping. AEA, CFM, and EDR analyzed the data. AEA and EDR wrote the manuscript. All authors read and approved the final manuscript.

\section{Funding}

This work was supported by the Consortium for FTD Research and Bluefield Project to Cure FTD, the National Institute on Aging (K99AG056597, K08AG052648, P01AG019724, P50AG023501), the National Institute of Neurological Disorders and Stroke (R01NS075487, P30NS47466), the Tau Consortium, and the Civitan International Research Center. The Lipidomics Shared Resource, Hollings Cancer Center, Medical University of South Carolina is supported by NIH grants P30CA138313 and P30G103339.

\section{Availability of data and materials}

All data generated or analyzed during this study are included in this published article.

\section{Ethics approval and consent to participate}

Brains were donated to the Neurodegenerative Disease Brain Bank at the University of California, San Francisco with the consent of the patients or their surrogates in accordance with the Declaration of Helsinki. The research was approved by the University of California, San Francisco Committee on Human Research. All animal experiments were approved by the Institutional Animal Care and Use Committee at the University of Alabama at Birmingham.

\section{Consent for publication}

Not applicable.

\section{Competing interests}

The authors declare that they have no competing interests.

\section{Author details}

${ }^{1}$ Departments of Neurology and Neurobiology, Center for Neurodegeneration and Experimental Therapeutics, Alzheimer's Disease Center, Evelyn F. McKnight Brain Institute, University of Alabama at Birmingham, Birmingham, AL, USA. ${ }^{2} 1825$ University Blvd., SHEL 1106 , Birmingham, AL 35294, USA. ${ }^{3}$ Department of Biostatistics, University of Alabama at Birmingham, Birmingham, AL, USA. ${ }^{4}$ Department of Psychiatry, David Geffen School of Medicine, University of California Los Angeles, Los Angeles, CA, USA. ${ }^{5}$ Department of Neurology, Memory \& Aging Center, UCSF Weill Institute for Neurosciences, University of California, San Francisco, San Francisco, CA, USA. 'Department of Pathology, University of California, San Francisco, San Francisco, CA, USA. ${ }^{7} 1825$ University Blvd., SHEL 1110, Birmingham, AL 35294, USA. 
Received: 28 October 2019 Accepted: 17 December 2019 Published online: 23 December 2019

\section{References}

1. Aflaki E, Westbroek W, Sidransky E (2017) The complicated relationship between Gaucher disease and parkinsonism: insights from a rare disease. Neuron 93:737-746. https://doi.org/10.1016/j.neuron.2017.01.018

2. Almeida MR, Macario MC, Ramos L, Baldeiras I, Ribeiro MH, Santana I (2016) Portuguese family with the co-occurrence of frontotemporal lobar degeneration and neuronal ceroid lipofuscinosis phenotypes due to progranulin gene mutation. Neurobiol Aging 41(200):e201-e205. https://doi. org/10.1016/j.neurobiolaging.2016.02.019

3. Arrant AE, Nicholson AM, Zhou X, Rademakers R, Roberson ED (2018) Partial Tmem106b reduction does not correct abnormalities due to progranulin haploinsufficiency. Mol Neurodegener 13:32. https://doi.org/10.1186/s13024018-0264-6

4. Arrant AE, Onyilo VC, Unger DE, Roberson ED (2018) Progranulin gene therapy improves Lysosomal dysfunction and microglial pathology associated with Frontotemporal dementia and neuronal Ceroid Lipofuscinosis. J Neurosci 38: 2341. https://doi.org/10.1523/JNEUROSCI.3081-17.2018

5. Baker M, Mackenzie IR, Pickering-Brown SM, Gass J, Rademakers R, Lindholm C, Snowden J, Adamson J, Sadovnick AD, Rollinson S et al (2006) Mutations in progranulin cause tau-negative frontotemporal dementia linked to chromosome 17. Nature 442:916-919

6. Beel S, Moisse M, Damme M, De Muynck L, Robberecht W, Van Den Bosch L, Saftig P, Van Damme P (2017) Progranulin functions as a cathepsin D chaperone to stimulate axonal outgrowth in vivo. Hum Mol Genet. https:// doi.org/10.1093/hmg/ddx162

7. Bendikov-Bar I, Ron I, Filocamo M, Horowitz M (2011) Characterization of the ERAD process of the L444P mutant glucocerebrosidase variant. Blood Cells Mol Dis 46:4-10. https://doi.org/10.1016/j.bcmd.2010.10.012

8. Bielawski J, Pierce JS, Snider J, Rembiesa B, Szulc ZM, Bielawska A (2009) Comprehensive quantitative analysis of bioactive sphingolipids by highperformance liquid chromatography-tandem mass spectrometry. Methods Mol Biol 579:443-467. https://doi.org/10.1007/978-1-60761-322-0_22

9. Boutin M, Sun Y, Shacka JJ, Auray-Blais C (2016) Tandem mass spectrometry multiplex analysis of Glucosylceramide and Galactosylceramide isoforms in brain tissues at different stages of Parkinson disease. Anal Chem 88:18561863. https://doi.org/10.1021/acs.analchem.5b04227

10. Brouwers N, Nuytemans K, van der Zee J, Gijselinck I, Engelborghs S, Theuns J, Kumar-Singh S, Pickut BA, Pals P, Dermaut B et al (2007) Alzheimer and Parkinson diagnoses in progranulin null mutation carriers in an extended founder family. Arch Neurol 64:1436-1446. https://doi.org/10.1001/archneur. 64.10 .1436

11. Butler VJ, Cortopassi WA, Argouarch AR, Ivry SL, Craik CS, Jacobson MP, Kao AW (2019) Progranulin stimulates the in vitro maturation of pro-Cathepsin D at acidic pH. J Mol Biol 431:1038-1047. https://doi.org/10.1016/j.jmb.2019.01.027

12. Butler VJ, Cortopassi WA, Gururaj S, Wang AL, Pierce OM, Jacobson MP, Kao AW (2019) Multi-Granulin domain peptides bind to pro-Cathepsin D and stimulate its enzymatic activity more effectively than Progranulin in vitro. Biochemistry 58:2670-2674. https://doi.org/10.1021/acs.biochem.9b00275

13. Chang KH, Chen CM, Chen YC, Hsiao YC, Huang CC, Kuo HC, Hsu HC, LeeChen GJ, Wu YR (2013) Association between GRN rs5848 polymorphism and Parkinson's disease in Taiwanese population. PLoS One 8:e54448. https://doi. org/10.1371/journal.pone.0054448

14. Chen Y, Jian J, Hettinghouse A, Zhao X, Setchell KDR, Sun Y, Liu CJ (2018) Progranulin associates with hexosaminidase a and ameliorates GM2 ganglioside accumulation and lysosomal storage in Tay-Sachs disease. J Mol Med (Berl) 96:1359-1373. https://doi.org/10.1007/s00109-018-1703-0

15. Chiasserini D, Paciotti S, Eusebi P, Persichetti E, Tasegian A, Kurzawa-Akanbi M, Chinnery PF, Morris CM, Calabresi P, Parnetti L et al (2015) Selective loss of glucocerebrosidase activity in sporadic Parkinson's disease and dementia with Lewy bodies. Mol Neurodegener 10:15. https://doi.org/10.1186/s13024015-0010-2

16. Cruts M, Gijselinck I, van der Zee J, Engelborghs S, Wils H, Pirici D, Rademakers R, Vandenberghe R, Dermaut B, Martin JJ et al (2006) Null mutations in progranulin cause ubiquitin-positive frontotemporal dementia linked to chromosome 17q21. Nature 442:920-924

17. Diner I, Nguyen T, Seyfried NT (2017) Enrichment of detergent-insoluble protein aggregates from human postmortem brain. J Vis Exp. https://doi. org/10.3791/55835
18. Filiano AJ, Martens LH, Young AH, Warmus BA, Zhou P, Diaz-Ramirez G, Jiao J, Zhang Z, Huang EJ, Gao FB et al (2013) Dissociation of frontotemporal dementia-related deficits and neuroinflammation in progranulin haploinsufficient mice. J Neurosci 33:5352-5361. https://doi.org/10.1523/ JNEUROSCI.6103-11.2013

19. Finch N, Baker M, Crook R, Swanson K, Kuntz K, Surtees R, Bisceglio G, Rovelet-Lecrux A, Boeve B, Petersen RC et al (2009) Plasma progranulin levels predict progranulin mutation status in frontotemporal dementia patients and asymptomatic family members. Brain 132:583-591. https://doi. org/10.1093/brain/awn352

20. Gass J, Cannon A, Mackenzie IR, Boeve B, Baker M, Adamson J, Crook R, Melquist S, Kuntz K, Petersen R et al (2006) Mutations in progranulin are a major cause of ubiquitin-positive frontotemporal lobar degeneration. Hum Mol Genet 15:2988-3001. https://doi.org/10.1093/hmg/ddl241

21. Gegg ME, Burke D, Heales SJ, Cooper JM, Hardy J, Wood NW, Schapira AH (2012) Glucocerebrosidase deficiency in substantia nigra of parkinson disease brains. Ann Neurol 72:455-463. https://doi.org/10.1002/ana.23614

22. Gegg ME, Sweet L, Wang BH, Shihabuddin LS, Sardi SP, Schapira AH (2015) No evidence for substrate accumulation in Parkinson brains with GBA mutations. Mov Disord 30:1085-1089. https://doi.org/10.1002/mds.26278

23. Gorno-Tempini ML, Hillis AE, Weintraub S, Kertesz A, Mendez M, Cappa SF, Ogar JM, Rohrer JD, Black S, Boeve BF et al (2011) Classification of primary progressive aphasia and its variants. Neurology 76:1006-1014. https://doi. org/10.1212/WNL.0b013e31821103e6

24. Gotzl JK, Colombo AV, Fellerer K, Reifschneider A, Werner G, Tahirovic S, Haass C, Capell A (2018) Early lysosomal maturation deficits in microglia triggers enhanced lysosomal activity in other brain cells of progranulin knockout mice. Mol Neurodegener 13:48. https://doi.org/10.1186/s13024018-0281-5

25. Götzl JK, Mori K, Damme M, Fellerer K, Tahirovic S, Kleinberger G, Janssens J, van der Zee J, Lang CM, Kremmer E et al (2014) Common pathobiochemical hallmarks of progranulin-associated frontotemporal lobar degeneration and neuronal ceroid lipofuscinosis. Acta Neuropathol 127: 845-860. https://doi.org/10.1007/s00401-014-1262-6

26. Grabowski GA (1997) Gaucher disease: gene frequencies and genotype/ phenotype correlations. Genet Test 1:5-12. https:/doi.org/10.1089/gte.1997.1.5

27. Grabowski GA, Horowitz M (1997) Gaucher's disease: molecular, genetic and enzymological aspects. Baillieres Clin Haematol 10:635-656. https://doi.org/ 10.1016/s0950-3536(97)80032-7

28. Jasinska-Myga B, Wider C, Opala G, Krygowska-Wajs A, Barcikowska M, Czyzewski K, Baker M, Rademakers R, Uitti RJ, Farrer MJ et al (2009) GRN $3^{\prime} U T R+78$ C >T is not associated with risk for Parkinson's disease. Eur J Neurol 16:909-911. https://doi.org/10.1111/j.1468-1331.2009.02621.x

29. Jian J, Tian QY, Hettinghouse A, Zhao S, Liu H, Wei J, Grunig G, Zhang W, Setchell KD, Sun Y et al (2016) Progranulin recruits HSP70 to betaGlucocerebrosidase and is therapeutic against Gaucher disease. EBioMedicine 13:212-224. https://doi.org/10.1016/j.ebiom.2016.10.010

30. Jian J, Zhao S, Tian QY, Liu H, Zhao Y, Chen WC, Grunig G, Torres PA, Wang BC, Zeng B et al (2016) Association between Progranulin and Gaucher disease. EBioMedicine 11:127-137. https://doi.org/10.1016/j.ebiom.2016.08.004

31. Kamate M, Detroja M, Hattiholi V (2019) Neuronal ceroid lipofuscinosis type11 in an adolescent. Brain and Development 41:542-545. https://doi.org/10. 1016/j.braindev.2019.03.004

32. Kelley BJ, Haidar W, Boeve BF, Baker M, Graff-Radford NR, Krefft T, Frank AR, Jack CR Jr, Shiung M, Knopman DS et al (2009) Prominent phenotypic variability associated with mutations in Progranulin. Neurobiol Aging 30: 739-751. https://doi.org/10.1016/j.neurobiolaging.2007.08.022

33. Klein ZA, Takahashi H, Ma M, Stagi M, Zhou M, Lam TT, Strittmatter SM (2017) Loss of TMEM106B ameliorates Lysosomal and Frontotemporal dementia-related phenotypes in Progranulin-deficient mice. Neuron 95:281296 e286. https://doi.org/10.1016/j.neuron.2017.06.026

34. Lambert JC, Ibrahim-Verbaas CA, Harold D, Naj AC, Sims R, Bellenguez C, DeStafano AL, Bis JC, Beecham GW, Grenier-Boley B et al (2013) Meta-analysis of 74,046 individuals identifies 11 new susceptibility loci for Alzheimer's disease. Nat Genet 45:1452-1458. https://doi.org/10.1038/ng.2802

35. Mackenzie IR, Neumann M, Baborie A, Sampathu DM, Du Plessis D, Jaros E, Perry RH, Trojanowski JQ, Mann DM, Lee VM (2011) A harmonized classification system for FTLD-TDP pathology. Acta Neuropathol 122:111113. https://doi.org/10.1007/s00401-011-0845-8

36. Mackenzie IR, Neumann M, Bigio EH, Cairns NJ, Alafuzoff I, Kril J, Kovacs GG, Ghetti B, Halliday G, Holm IE et al (2010) Nomenclature and nosology for 
neuropathologic subtypes of frontotemporal lobar degeneration: an update. Acta Neuropathol 119:1-4. https://doi.org/10.1007/s00401-009-0612-2

37. Martens LH, Zhang J, Barmada SJ, Zhou P, Kamiya S, Sun B, Min S-W, Gan L, Finkbeiner S, Huang EJ et al (2012) Progranulin deficiency promotes neuroinflammation and neuron loss following toxin-induced injury. J Clin Invest 122:3955-3959

38. Mazzulli JR, Xu YH, Sun Y, Knight AL, McLean PJ, Caldwell GA, Sidransky E, Grabowski GA, Krainc D (2011) Gaucher disease glucocerebrosidase and alpha-synuclein form a bidirectional pathogenic loop in synucleinopathies. Cell 146:37-52. https://doi.org/10.1016/j.cell.2011.06.001

39. Moors TE, Paciotti S, Ingrassia A, Quadri M, Breedveld G, Tasegian A, Chiasserini D, Eusebi P, Duran-Pacheco G, Kremer T et al (2019) Characterization of brain Lysosomal activities in GBA-related and sporadic Parkinson's disease and dementia with Lewy bodies. Mol Neurobiol 56: 1344-1355. https://doi.org/10.1007/s12035-018-1090-0

40. Mullen RJ, Buck CR, Smith AM (1992) NeuN, a neuronal specific nuclear protein in vertebrates. Development 116:201-211

41. Nalls MA, Blauwendraat C, Vallerga CL, Heilbron K, Bandres-Ciga S, Chang D, Tan M, Kia DA, Noyce AJ, Xue A et al (2019) Expanding Parkinson's disease genetics: novel risk loci, genomic context, causal insights and heritable risk. bioRxiv:388165. https://doi.org/10.1101/388165

42. Nalls MA, Duran R, Lopez G, Kurzawa-Akanbi M, McKeith IG, Chinnery PF, Morris CM, Theuns J, Crosiers D, Cras P et al (2013) A multicenter study of glucocerebrosidase mutations in dementia with Lewy bodies. JAMA Neurol 70:727-735. https://doi.org/10.1001/jamaneurol.2013.1925

43. Neary D, Snowden JS, Gustafson L, Passant U, Stuss D, Black S, Freedman M, Kertesz A, Robert PH, Albert M et al (1998) Frontotemporal lobar degeneration: a consensus on clinical diagnostic criteria. Neurology 51:1546-1554

44. Nelson MP, Boutin M, Tse TE, Lu H, Haley ED, Ouyang X, Zhang J, Auray-Blais C, Shacka JJ (2018) The lysosomal enzyme alpha-Galactosidase a is deficient in Parkinson's disease brain in association with the pathologic accumulation of alphasynuclein. Neurobiol Dis 110:68-81. https://doi.org/10.1016/.jnbd.2017.11.006

45. Nicholson AM, Finch NA, Almeida M, Perkerson RB, van Blitterswijk M, Wojtas A, Cenik B, Rotondo S, Inskeep V, Almasy L et al (2016) Prosaposin is a regulator of progranulin levels and oligomerization. Nat Commun 7:11992. https://doi.org/10.1038/ncomms11992

46. Nilsson O, Svennerholm L (1982) Accumulation of glucosylceramide and glucosylsphingosine (psychosine) in cerebrum and cerebellum in infantile and juvenile Gaucher disease. J Neurochem 39:709-718. https://doi.org/10 1111/j.1471-4159.1982.tb07950.x

47. Nuytemans K, Pals P, Sleegers K, Engelborghs S, Corsmit E, Peeters K, Pickut B, Mattheijssens M, Cras P, De Deyn PP et al (2008) Progranulin variability has no major role in Parkinson disease genetic etiology. Neurology 71: 1147-1151. https://doi.org/10.1212/01.wnl.0000327563.10320.2b

48. O'Regan G, deSouza RM, Balestrino R, Schapira AH (2017) Glucocerebrosidase mutations in Parkinson disease. J Park Dis 7:411-422. https://doi.org/10.3233/JPD-171092

49. Orvisky E, Park JK, LaMarca ME, Ginns El, Martin BM, Tayebi N, Sidransky E (2002) Glucosylsphingosine accumulation in tissues from patients with Gaucher disease: correlation with phenotype and genotype. Mol Genet Metab 76:262-270. https://doi.org/10.1016/s1096-7192(02)00117-8

50. Palop JJ, Mucke L, Roberson ED (2011) Quantifying biomarkers of cognitive dysfunction and neuronal network hyperexcitability in mouse models of Alzheimer's disease: depletion of calcium-dependent proteins and inhibitory hippocampal remodeling. In: Roberson ED (ed) Alzheimer's disease and Frontotemporal dementia: methods and protocols. Humana Press, Totowa, pp 245-262

51. Pilotto A, Schulte C, Hauser AK, Biskup S, Munz M, Brockmann K, Schaeffer E, Synofzik M, Maetzler W, Suenkel U et al (2016) GBA-associated parkinsonism and dementia: beyond alpha-synucleinopathies? Eur J Neurol 23:520-526. https://doi.org/10.1111/ene.12894

52. Ramos EM, Dokuru DR, Van Berlo V, Wojta K, Wang Q, Huang AY, Miller ZA, Karydas AM, Bigio EH, Rogalski E et al (2019) Genetic screen in a large series of patients with primary progressive aphasia. Alzheimers Dement 15:553560. https://doi.org/10.1016/j.jalz.2018.10.009

53. Rascovsky K, Hodges JR, Knopman D, Mendez MF, Kramer JH, Neuhaus J, van Swieten JC, Seelaar H, Dopper EG, Onyike CU et al (2011) Sensitivity of revised diagnostic criteria for the behavioural variant of frontotemporal dementia. Brain 134:2456-2477. https://doi.org/10.1093/brain/awr179

54. Richards S, Aziz N, Bale S, Bick D, Das S, Gastier-Foster J, Grody WW, Hegde M, Lyon E, Spector E et al (2015) Standards and guidelines for the interpretation of sequence variants: a joint consensus recommendation of the American College of Medical Genetics and Genomics and the Association for Molecular Pathology. Genet Med 17:405-424. https://doi.org/10.1038/gim.2015.30

55. Rocha EM, Smith GA, Park E, Cao H, Brown E, Hallett P, Isacson O (2015) Progressive decline of glucocerebrosidase in aging and Parkinson's disease. Ann Clin Transl Neurol 2:433-438. https://doi.org/10.1002/acn3.177

56. Rovelet-Lecrux A, Deramecourt V, Legallic S, Maurage CA, Le Ber I, Brice A, Lambert $J$ C, Frebourg T, Hannequin D, Pasquier F et al (2008) Deletion of the progranulin gene in patients with frontotemporal lobar degeneration or Parkinson disease. Neurobiol Dis 31:41-45. https://doi.org/10.1016/j.nbd.2008.03.004

57. Sandhoff R, Sandhoff K (2018) Emerging concepts of ganglioside metabolism. FEBS Lett 592:3835-3864. https://doi.org/10.1002/1873-3468.13114

58. Schulze H, Sandhoff K (2014) Sphingolipids and lysosomal pathologies. Biochim Biophys Acta 1841:799-810. https://doi.org/10.1016/j.bbalip.2013.10.015

59. Smith KR, Damiano J, Franceschetti S, Carpenter S, Canafoglia L, Morbin M, Rossi G, Pareyson D, Mole SE, Staropoli JF et al (2012) Strikingly different clinicopathological phenotypes determined by progranulinmutation dosage. Am J Hum Genet 90:1102-1107. https://doi.org/10. 1016/j.ajhg.2012.04.021

60. St Martin JL, Klucken J, Outeiro TF, Nguyen P, Keller-McGandy C, CantutiCastelvetri I, Grammatopoulos TN, Standaert DG, Hyman BT, McLean PJ (2007) Dopaminergic neuron loss and up-regulation of chaperone protein mRNA induced by targeted over-expression of alpha-synuclein in mouse substantia nigra. J Neurochem 100:1449-1457. https://doi.org/10.1111/j. 1471-4159.2006.04310.x

61. Tanaka Y, Matsuwaki T, Yamanouchi K, Nishihara M (2013) Increased lysosomal biogenesis in activated microglia and exacerbated neuronal damage after traumatic brain injury in progranulin-deficient mice. Neuroscience 250:8-19. https://doi.org/10.1016/j.neuroscience.2013.06.049

62. Tanaka Y, Suzuki G, Matsuwaki T, Hosokawa M, Serrano G, Beach TG, Yamanouchi K, Hasegawa M, Nishihara M (2017) Progranulin regulates lysosomal function and biogenesis through acidification of lysosomes. Hum Mol Genet 26:969-988. https://doi.org/10.1093/hmg/ddx011

63. Tsuang D, Leverenz JB, Lopez OL, Hamilton RL, Bennett DA, Schneider JA, Buchman AS, Larson EB, Crane PK, Kaye JA et al (2012) GBA mutations increase risk for Lewy body disease with and without Alzheimer disease pathology. Neurology 79:1944-1950. https://doi.org/10.1212/WNL. 0b013e3182735e9a

64. Valdez C, Wong YC, Schwake M, Bu G, Wszolek ZK, Krainc D (2017) Progranulin-mediated deficiency of cathepsin D results in FTD and NCL-like phenotypes in neurons derived from FTD patients. Hum Mol Genet. https:// doi.org/10.1093/hmg/ddx364

65. Valdez C, Ysselstein D, Young TJ, Zheng J, Krainc D (2019) Progranulin mutations result in impaired processing of prosaposin and reduced glucocerebrosidase activity. Hum Mol Genet. https:/doi.org/10.1093/hmg/ddz229

66. Van Kampen JM, Baranowski D, Kay DG (2014) Progranulin gene delivery protects dopaminergic neurons in a mouse model of Parkinson's disease. PLoS One 9:e97032. https://doi.org/10.1371/journal.pone.0097032

67. Ward ME, Chen R, Huang HY, Ludwig C, Telpoukhovskaia M, Taubes A, Boudin H, Minami SS, Reichert M, Albrecht P et al (2017) Individuals with progranulin haploinsufficiency exhibit features of neuronal ceroid lipofuscinosis. Sci Transl Med 9:eaah5642. https://doi.org/10.1126/ scitransImed.aah5642

68. Wauters E, Van Mossevelde S, Sleegers K, van der Zee J, Engelborghs S, Sieben A, Vandenberghe R, Philtjens S, Van den Broeck M, Peeters K et al (2018) Clinical variability and onset age modifiers in an extended Belgian GRN founder family. Neurobiol Aging 67:84-94. https://doi.org/10.1016/j. neurobiolaging.2018.03.007

69. Wendeler M, Sandhoff K (2009) Hexosaminidase assays. Glycoconj J 26:945952. https://doi.org/10.1007/s10719-008-9137-5

70. Yun SP, Kim D, Kim S, Kim S, Karuppagounder SS, Kwon SH, Lee S, Kam TI, Lee S, Ham S et al (2018) Alpha-Synuclein accumulation and GBA deficiency due to L444P GBA mutation contributes to MPTP-induced parkinsonism. Mol Neurodegener 13:1. https://doi.org/10.1186/s13024-017-0233-5

71. Zhou X, Paushter DH, Feng T, Pardon CM, Mendoza CS, Hu F (2017) Regulation of cathepsin D activity by the FTLD protein progranulin. Acta Neuropathol. https://doi.org/10.1007/s00401-017-1719-5

72. Zhou X, Paushter DH, Pagan MD, Kim D, Nunez Santos M, Lieberman RL, Overkleeft HS, Sun Y, Smolka MB, Hu F (2019) Progranulin deficiency leads to reduced glucocerebrosidase activity. PLoS One 14:e0212382. https://doi. org/10.1371/journal.pone.0212382 
73. Zhou X, Sun L, Bastos de Oliveira F, Qi X, Brown WJ, Smolka MB, Sun Y, Hu $F$ (2015) Prosaposin facilitates sortilin-independent lysosomal trafficking of progranulin. J Cell Biol 210:991-1002. https://doi.org/10.1083/jcb.201502029

74. Zhou X, Sun L, Bracko O, Choi JW, Jia Y, Nana AL, Brady OA, Hernandez JCC, Nishimura N, Seeley WW et al (2017) Impaired prosaposin lysosomal trafficking in frontotemporal lobar degeneration due to progranulin mutations. Nat Commun 8:15277. https://doi.org/10.1038/ncomms15277

\section{Publisher's Note}

Springer Nature remains neutral with regard to jurisdictional claims in published maps and institutional affiliations.

Ready to submit your research? Choose BMC and benefit from:

- fast, convenient online submission

- thorough peer review by experienced researchers in your field

- rapid publication on acceptance

- support for research data, including large and complex data types

- gold Open Access which fosters wider collaboration and increased citations

- maximum visibility for your research: over $100 \mathrm{M}$ website views per year

At $B M C$, research is always in progress.

Learn more biomedcentral.com/submissions 